https://doi.org/10.18778/8088-222-5.11

Anna Kacperczyk

\author{
„NIE MUSZE SIE TAK BAĆ!” \\ ROLA AUTOETNOGRAFII W ANALIZIE EMOCJONALNYCH \\ ASPEKTÓW DZIAŁANIA WSPINACZKOWEGO ${ }^{1}$
}

Strach, jak grawitacja, jest zawsze obecny więc nieustannie $z$ nim walczymy.

Don McGrath, Jeff Elison (2014: 70)

\title{
Tło analizy
}

Analiza niniejsza powstała $\mathrm{w}$ ramach szerszego projektu badawczego majacego na celu opis społecznego świata wspinaczki ${ }^{2}$. Społeczny świat tworzą ludzie zaangażowani w pewną działalność, która dla obserwatora pozostaje „uderzająco ewidentna”, a dla samych działających oczywista. Owa podstawowa działalność (ang. primary activity), która udaje się łatwo wskazać i wyróżnić na tle wielu innych aktywności podejmowanych przez uczestników, stanowi najistotniejsza cechę, a zarazem zasadnicze kryterium definicyjne społecznego świata (Strauss 1978: 22, 1987: 230). W tym

${ }^{1}$ Artykuł niniejszy opiera sie na referacie wygłoszonym na X Konferencji European Sociological Association, która odbyła się w Genewie (Szwajcaria) w dniach 7-10 września 2011 roku i nosiła tytuł Social Relations in Turbulent Times.

2 Projekt ten prowadziłam w latach 2007-2014 w ramach przygotowywania rozprawy habilitacyjnej pt. Społeczne światy. Teoria - empiria - metody badań. Na przykładzie analizy społecznego świata wspinaczki (Kacperczyk 2016). Por. też Kacperczyk (2010, 2012, 2013). 
sensie możemy mówić o niezliczonych światach, które łączą ludzi i angażują ich wokół działań określonego rodzaju ${ }^{3}$.

Moim celem było rozpoznanie oraz opis podstawowych procesów i działań podejmowanych w społecznym świecie wspinaczki. Poza tym zamierzeniem eksploracyjnym związanym $z$ konkretnym obszarem substantywnym, jakim jest podejmowanie przez ludzi aktywności wspinaczkowej, stawiałam sobie cel metodologiczny dotyczący tego, jak badać światy społeczne, jakich metod i podejść badawczych używać, by efektywnie przeprowadzić analizę tego rodzaju oraz cel teoretyczny, zwiąany $z$ ewentualnym pogłębieniem lub rozbudowaniem samej teorii światów społecznych ${ }^{4}$.

Zbieranie danych rozpoczęłam w marcu 2007 roku (por. m.in. Kacperczyk 2010, 2012, 2013) od słuchania wywiadów radiowych $z$ polskimi alpinistami i himalaistami, które utrwalałam w postaci plików audio, by następnie poddać je transkrypcji oraz analizie zgodnej $z$ procedurami metodologii teorii ugruntowanej (kodowanie otwarte, selektywne, pisanie not teoretycznych). W celu wygenerowania bogatszych kategorii analitycznych na temat dyskursów powiązanych $z$ działaniem podstawowym, zaczęłam czytać czasopisma i magazyny o tematyce górskiej i wspinaczkowej oraz przeszukiwać strony internetowe poświęcone wspinaniu. Natknęłam się na liczne dyskusje dotyczace działania podstawowego prowadzone na wspinaczkowych portalach oraz forach internetowych, a także

3 Anselm L. Strauss (1964) i Howard S. Becker (1974, 1986) definiują światy społeczne jako grupy podzielające wspólne zobowiąanie do angażowania się w pewna działalność, dzielące ze sobą rozmaite zasoby pozwalające im osiagać ich cele oraz wytwarzajace kolektywną ideologię odnoszaccą się do tego, jak prowadzić dane działanie. Adele E. Clarke (1991: 131) opisuje świat społeczny w kategoriach tradycyjnego pojęcia środowiska społecznego - jako „świat czegoś: teatru, wojska, baseballu, wyścigów konnych, polityki narodowej lub międzynarodowego bankingu (por. Strauss 1993: 212). Najważniejsze pojęcia związane $z$ teoria światów społecznych to: działanie podstawowe (ang. primary activity), technologia (ang. technology), płynne granice (ang. fluid boundaries), areny (ang. arenas), procesy legitymizacji (ang. legitimation processes), segmentacji (ang. segmentation), przecinania się (ang. intersection), profesjonalizacji (ang. professionalization) - por. Kacperczyk (2005).

4 Teoretyczna podstawa badania był symboliczny interakcjonizm (Blumer 2007 [1969]), a szczególnie teoria światów społecznych (Cressey 2008 [1932]; Shibutani 1955; Strauss 2013 [1959], 1987, 1993; Strauss i in. 1964; Becker 1974, 1982; Clarke 1987, 1990, 1991, 2003, 2005; Star 1989; Fujiumura 1996, 1997; Wiener 1981; Kling, Gerson 1977, 1978), natomiast bazę metodologiczną stanowiła teoria ugruntowana wraz $z$ jej pragmatyczna wizja działania oraz metoda ciagłego porównywania oraz teoretycznego pobierania próbek (Glaser, Strauss 2009 [1967]; Clarke 2005; Charmaz 2009). 
na strony internetowe oraz blogi prowadzone przez wspinaczy i zawierajace bogate materiały autonarracyjne dotyczace karier wspinaczkowych, rozwoju umiejętności oraz uwarunkowań działalności wspinaczkowej. Głównym problemem na tym etapie badania była bariera językowa związana $z$ hermetycznym językiem, jakim posługiwali się wspinacze w swoich wypowiedziach. Czytając ich teksty $z$ ogromnym trudem przedzierałam się przez techniczne słownictwo dotyczace sprzętu wspinaczkowego, operacji linowych, nazw poszczególnych czynności oraz ocen i charakterystyk samego działania. Na tym etapie pracowałam nieustannie $z$ leksykonami alpinizmu, słownikami pojęć wspinaczkowych oraz Wikipedią. Po paru miesiącach rozpoznawałam już znaczenia większości pojęć związanych $z$ technologia wspinaczkową. Miałam jednak poczucie, że nadal nie rozumiem istoty czynności i operacji opisywanych przez te pojęcia. Czułam też, że nadmierna koncentracja na technologicznych aspektach działania przesłania mi obraz całości. Uznałam, że tę barierę technologiczna mogę pokonać tylko w jeden sposób - ucząc się jej użycia. Potrzebowałam kogoś, kto pokazałby mi $\mathrm{w}$ praktyce, na czym polegaja operacje sprzętowe podczas wspinania i jak je poprawnie wykonywać. Uważałam, że to pozwoli mi lepiej zrozumieć rolę i zakres skomplikowanej alpinistycznej technologii w działaniu wspinaczkowym oraz zredukuje moja skłonność do przeceniania tego aspektu wspinaczki i postrzegania go jako zagadnienia dominującego $\mathrm{w}$ analizie. To doprowadziło mnie do decyzji zaangażowania się $\mathrm{w}$ proces szkoleniowy w charakterze adepta. Wykorzystałam jedna ze standardowych dróg stawania się uczestnikiem - zapisałam się na kurs wspinaczkowy ${ }^{5}$.

Szybko zorientowałam się, że wiele $z$ poszukiwanych przeze mnie informacji jest możliwych do uchwycenia w konwersacjach, wywiadach i narracjach samych wspinaczy oraz w materiałach audiowizualnych, ale niektóre aspekty wspinania, doświadczane przeze mnie sama, nie pojawiaja się w rozmowach, sa trudne do wyrażenia za pomoca ekspresji werbalnej lub w ogóle nie sa przepracowywane słownie przez uczestników studiowanego świata. Chociaż badanie świata wspinaczki bazuje głównie na danych

${ }^{5}$ W latach 2007-2008 przeszłam trzy takie kursy. Najpierw 6-dniowy letni kurs skałkowy w Dolinie Kobylańskiej, zorganizowany przez prywatna szkołę wspinaczki. Następnie 7-miesięczny kurs wspinaczkowy w klubie górskim zrzeszonym w Polskim Związku Alpinizmu, na który składał się cykl 20 wykładów na temat wspinania, kurs wspinania ściankowego oraz dwa czterodniowe wyjazdy w skały. Oprócz tego przeszłam kurs autoratownictwa górskiego. 
o charakterze dyskursywnym, zwerbalizowanych i tekstowych - sama istota działania wspinaczkowego leży poza słowami. Akt wspinania wiąże się $z$ doświadczeniem ruchu ciała, operacjami manualnymi oraz technicznymi umiejętnościami o charakterze kinestetycznym, pozwalającymi dokonać bezpiecznego przejścia drogi wspinaczkowej. Nawet jeśli uznamy, że wspinanie to szczególny rodzaj „konwersacji” czy też interakcji, jaką wspinacz prowadzi ze skała przy pomocy własnego ciała, to i tak esencja tego działania leży poza dyskursem, sam akt wspinania odbywa się poprzez ciało i przy użyciu ciała (por. Kacperczyk 2012), w przestrzeni fizycznej - stawiajacej podmiotowi twarde wymagania - a nie w przestrzeni werbalnej. Świadomość tego stanowiła dla mnie dodatkowy argument, by spróbować się wspinać i zobaczyć ,jak to jest” podejmować działanie wspinaczkowe.

W badaniu światów społecznych podstawowe pytanie dotyczy tego, co ludzie robią i jak się zachowują, jak wygląda ich działanie w praktyce, dlatego istotne jest, by obserwować uczestników w naturalnych sytuacjach działania. Stąd podejście etnograficzne wydawało się najbardziej adekwatne. Pozostawało też w zgodzie $z$ moim przekonaniem, że podstawą dobrej teorii musi być dobra etnografia. Mój pomysł na badanie polegał na użyciu wielu różnorodnych metod i technik otrzymywania materiałów połączonych $z$ analiza bogatych materiałów zastanych. Prowadziłam obserwacje sytuacji wspinania $^{6}$ oraz wywiady ze wspinaczami ${ }^{7}$, dodatkowo gromadziłam materiały wizualne (fotografie, filmy dokumentalne, nagrania wideo), biograficzne i narracyjne (autobiografie wspinaczy, artykuły w prasie alpinistycznej i wspinaczkowej, blogi wspinaczy). W su-

6 Spędziłam wiele godzin na sztucznych ściankach wspinaczkowych oraz $\mathrm{w}$ rejonach skalnych w Polsce prowadzac obserwację, rozmawiając ze wspinaczami, realizujacc wywiady, robiąc zdjęcia i nagrania wideo i wspinając się. Obserwacja uczestniczaca obejmowała sytuacje: kursu wspinaczki skalnej, kursu autoasekuracji i autoratownictwa górskiego, wykładów na temat wspinania organizowanych przez kluby górskie, publicznych pokazów slajdów relacjonujących odbyte wyprawy górskie, treningi na ściankach klubowych (głównie Akademickiego Klubu Górskiego w Łodzi) oraz na ściankach komercyjnych, weekendowego wspinania w rejonach skałkowych w Polsce (Dolina Kobylańska, Jerzmanowice, Witkowe Skały, Rzędkowice, Mirów, Góra Zborów, Góry Sokole).

7 Przeprowadziłam 30 wywiadów $z$ osobami reprezentujacymi różne dyscypliny wspinania: wspinanie skałkowe, taternictwo, alpinizm, himalaizm, himalaizm zimowy, wspinanie wielkościanowe, wspinanie w lodzie oraz drytooling (czyli wspinanie po skale przy użyciu narzędzi stosowanych we wspinaczce lodowej - raków i czekanów). Najmłodszy uczestnik badania miał 15 lat, najstarszy 82 lata. Średnia wieku badanych to 40 lat. 
mie $\mathrm{w}$ realizowanym projekcie zaangażowałam zarówno elementy etnografii (obserwacje, rozmowy i wywiady, analiza materiałów zastanych); netnografii ${ }^{8}$ (analiza zawartości stron internetowych, blogów, portali wspinaczkowych i forów dyskusyjnych poświęconych wspinaniu) oraz autoetnografii (autoobserwacja własnego uczestnictwa w sytuacjach wspinania, przechodzenia kursów wspinaczkowych oraz podejmowania treningu wspinaczkowego).

W swoim podejściu podażałam za wytycznymi autoetnografii analitycznej, zaproponowanymi przez Leona Andersona (2006, 2014), zgodnie $z$ którymi badacz jest (1) pełnym uczestnikiem badanej grupy, (2) jest widoczny jako badacz w tworzonych przez siebie materiałach oraz publikowanych tekstach i (3) pozostaje zaangażowany w zadania analityczne prowadzace do generowania teorii pozwalajacych zrozumieć szersze fenomeny społeczne (Anderson 2006: 375).

\section{Śledzenie emocjonalnych aspektów działalności wspinaczkowej}

Początkowo temat emocji przeżywanych przez badanych podczas wspinania był marginalnym przedmiotem mojego zainteresowania badawczego. Interesowało mnie głównie działanie wspinaczkowe - jak przebiega, jak jest realizowane, jakie sa jego uwarunkowania. Szybko jednak okazało się, że sytuacja wspinania wzbudza liczne emocje. Podczas wspinaczki ludzie odczuwaja strach, lęk, złość, wściekłość, furię, frustrację, euforię, radość, szczęście, dumę, a emocje te sa $\mathrm{w}$ istotny sposób powiazane $z$ samym działaniem, wpływają na efektywność wspinacza i jego możliwości poradzenia sobie $z$ wyzwaniem górskim. Moja szczególną uwage przyciagały emocje przeżywanego strachu i lęku, nawiązywały bowiem do kodów przewijających się od samego początku badania, a związanych $z$ niebezpieczeństwami terenu górskiego oraz zagrożeniami obecnymi w każdej akcji wspinaczkowej (por. Kacperczyk 2010).

Sama sytuacja wspinania zawiera w sobie specyficzne cechy wpływające na działanie. Przede wszystkim akt wspinania oznacza

8 Netnografia lub cybernetnografia to szczególna odmiana etnografii zaadaptowana do badania społeczności internetowych oraz wirtualnych aspektów życia społecznego. Pojęcie netnografii wprowadził Robert V. Kozinets (1998: 366), nazywając $\mathrm{w}$ ten sposób marketingowe badanie cyberkultury i podkreślając odrębność i odmienność prowadzenia badań etnograficznych on-line. 
nabieranie wysokości, a jednocześnie kumulowanie energii kinetycznej do upadku. To może budzić lęk i wywoływać strach. Bardzo często wspinanie przebiega na dużych wysokościach, w miejscach eksponowanych, czyli wystawionych na szeroka otwarta przestrzeń, rozciagających się ponad otchłanią, w których wspinacz widzi pod stopami tylko powietrze (w żargonie wspinaczkowym - luft) i nie ma wygodnej półki, na której mógłby pewnie stanąc. Takie warunki działania określane przez wspinaczy jako przepaścistość lub powietrzność drogi wspinaczkowej stanowia ogromne wyzwanie psychiczne, ale jednocześnie są źródłem niepowtarzalnych przeżyć i podnosza ocenę i wartość pokonywanej drogi. To wymusza na wspinaczu konieczność zmierzenia się $z$ widokiem przepaści i pokonania nieprzyjemnego uczucia spowodowanego brakiem oparcia dla stóp. Aby kontynuować wspinanie w tak ogromnej ekspozycji wspinacz musi zwalczyć swój lęk przed ekspozycją i skoncentrować się na działaniu. Generalnie wspinacze by osiagać swoje cele muszą nauczyć się pokonywać lęk wysokości.

Kolejna cechą działalności wspinaczkowej jest możliwe odpadnięcie od ściany i upadek $z$ wysokości. Wspinanie zawsze zawiera w sobie ryzyko lotu, dlatego wspinacz musi zmierzyć się z lękiem przed odpadnięciem i nauczyć się, jak spadać, by bezpiecznie wylądować i się nie uszkodzić. Możliwe konsekwencje obejmują w najlepszym razie siniaki i urazy, w najgorszym ciężkie uszkodzenia ciała, a nawet śmierć9. Wspinacze ucza się jak rozpoznawać zagrożenia podczas wspinaczki, jak poprawie reagować, gdy sytuacja jest niebezpieczna. Ucza się, by w skałach i górach zachowywać czujność, a podczas działań górskich i wspinaczkowych wykonuja nieustanna pracę nad bezpieczeństwem.

Tak więc temat przeżywanego lęku oraz strachu wydaje się być immanentną częścią aktywności wspinaczkowej. Lęk przed ekspozycja, przed odpadnięciem od ściany, przed upadkiem, przed lotem, przed wyrwaniem punktu asekuracyjnego - jest stale obecny w polu doświadczeń wspinaczy. Wszystkie te emocje odnoszą się do doświadczenia związanego $z$ antycypowaniem jednego $z$ najbardziej nieprzyjemnych odczuć - utraty kontaktu $z$ gruntem i braku bez-

${ }^{9}$ Współcześnie odpadnięcia we wspinaczce są relatywnie bezpieczne dzięki nowoczesnej technologii i zaawansowanym systemom asekuracyjnym takim jak: liny dynamiczne pochłaniające energię odpadnięcia, uprzęże, przyrządy hamujace, stałe punkty asekuracyjne wmontowane w skałę. Elementy te pozwalaja doświadczać lotów bez groźnych konsekwencji - oczywiście pod warunkiem, że sprzęt wspinaczkowy jest poprawnie używany. 
piecznego oparcia dla stóp oraz ze stojącym za nimi lękiem przed uszkodzeniem ciała. Emocje te sa silnie osadzone w odczuciach cielesnych i doświadczeniach kinestetycznych podmiotu. Zazwyczaj instynktownie unikamy sytuacji wywołujacych tego rodzaju doświadczenia, ponieważ sa one źródłem strachu, a jednocześnie sygnałem realnego zagrożenia.

Strach traktowany jest przez psychologów jako emocja kluczowa dla przetrwania organizmu, odgrywająca decydująca rolę w zachowaniu zdrowia i życia. Jest on aktywizowany automatycznie w sytuacji bezpośredniego zagrożenia życia czy zbliżającego się uszkodzenia ciała. Wzbudzony strach aktywizuje nerwy ruchowe i uruchamia systemy wewnątrzwydzielnicze, przygotowując organizm do zmierzenia się $z$ zagrażająca nam sytuacją.

Jednak poza tym wymiarem biologicznym, strach - jak każda inna emocja - stanowi zarazem wytwór kulturowy ${ }^{10}$, którego opracowania i subtelnych znaczeń trzeba się nauczyć (Lutz 1988: 9). Pojawianie się emocji oraz nadawane im znaczenia sa „negocjowane, ignorowane, uprawomocniane przez ludzi pozostajacych w relacjach społecznych" (Tamże: 212) ${ }^{11}$. Ostatecznie sama forma pracy nad strachem odsłania kulturową konstrukcję niebezpieczeństwa (Warren 1979: 359). Na plastyczność emocji oraz ich podatność na społeczne konstruowanie wskazuja także Susan Shott ${ }^{12}$ (1979: 1321) oraz Stanley S. Schachter ${ }^{13}$ (1971: 23-24).

${ }^{10}$ W ujęciu Catherine A. Lutz (1998: 5) znaczenie emocji jest konstruowane przez konkretny system kulturowy i pozostaje częścia jego lokalnych praktyk ideologicznych. Praca nad emocjami zakłada negocjacje dotyczące znaczenia zdarzeń, obowiązujących praw, moralności, kontroli zasobów - co wymaga podejmowania szeregu wysiłków zarówno na poziomie kolektywnym, jak i indywidualnym. Nazywanie emocji, usprawiedliwianie ich czy perswadowanie zawsze jest procesem społecznym, w którym ludzie odnoszą się do siebie nawzajem. Tak więc, choć doświadczamy emocji jako czegoś, co pojawia się w granicach naszego ciała - pozostaja one produktem życia zbiorowego, maja pochodzenie społeczne.

11 Jednym $z$ przykładów świadczących o społecznym konstruowaniu emocji może być oczekiwanie przez wspinacza niecodziennych odczuć w chwili zdobycia szczytu oraz jego konstatacja, że w istocie stojąc $\mathrm{w}$ tym upragnionym przez siebie miejscu nie czuje nic (por. Kacperczyk 2013: 78).

12 Autorka ta pisze o dwóch ontogenetycznych procesach społecznych bioracych udział w powstawaniu emocji: (i) socjalizacji emocji, pozwalajacej jednostkom nauczyć się odpowiedniego odczuwania i nazywania własnych emocji typowych dla doświadczeń afektywnych własnej kultury oraz (ii) konstruowaniu emocji przez aktora, które pojawia się w konkretnej sytuacji działania i zależy od przyjmowanych przez jednostkę definicji sytuacji oraz norm społecznych (Shott 1979: 1318).

13 Schachter twierdzi, że $z$ emocja mamy do czynienia dopiero wówczas, gdy stan fizjologicznego pobudzenia (ang. physiological arousal) zostanie przez 
Wszystkie te aspekty oddziaływania emocji na sytuację wspinania, przykuwały moją uwage i skłaniały do wyodrębnienia w ramach kodowania selektywnego ${ }^{14}$ całej puli kategorii analitycznych powiązanych ze strachem oraz lękiem przė̇ywanym i przepracowywanym przez wspinaczy. Interesowało mnie, jak doświadczane sa przez nich te emocje, jak radza sobie $z$ nimi, oraz ogólnie - jak te szczególne emocje „pracuja” w sytuacji wspinania. Momentem inicjującym oraz strukturyzujacym cały proces analizy stała się przypadkowa obserwacja dokonana przeze mnie w trakcie działalności skałkowej.

\section{Obserwacja uczestnicząca}

Podczas jednego $z$ pobytów w rejonie skałkowym w Polsce, ponad dwa lata po tym, jak rozpoczęłam gromadzenie i analizę danych, byłam świadkiem sytuacji rodzinnej wspinaczki w uderzający sposób odnoszącej się do moich osobistych doświadczeń $z$ początków wspinania, których dotąd nie potrafiłam ustrukturalizować ani włączyć do pogłębionej analizy.

Przypadek 1. Kontekst: Rejon skałkowy w Polsce. Pod skała ja i mój partner wspinaczkowy spotykamy rodzinę $z$ dziećmi. Na drodze piatkowej ${ }^{15}$ - zawieszona wędka ${ }^{16}$. Chłopiec lat ok. 8-9 szykuje się do

aktora społecznego zdefiniowany jako wywołany emocjonalnie. Podmiot musi więc swoje pobudzenie fizjologiczne poznawczo oznaczyć jako afekt, czyli nadać mu kognitywną etykietę emocji (cognitive labeling as affect) (Schachter 1971: 23-24).

${ }^{14} \mathrm{~W}$ metodologii teorii ugruntowanej faza kodowania selektywnego wiąże się $z$ decyzją badacza o skoncentrowaniu swojej uwagi na pewnym watku lub temacie, który badacz wybiera do dalszej pogłębionej analizy. Polega to na wskazaniu kategorii centralnej, wokół której ogniskować się będzie praca analityczna i którą badacz będzie próbował uchwycić konceptualnie (Glaser 1978: 61; Konecki 2000: $52)$.

${ }^{15}$ Droga „piątkowa”, to określenie wyceny trudności danej drogi na jednej z funkcjonujących w polskim środowisku wspinaczkowym skal trudności (tzw. skali krakowskiej lub skali Kurtyki - od nazwiska jej twórcy). Skala ta określa trudności techniczne wspinaczki skalnej i wygląda następująco: I, II, III, IV, IV+, V-, V, V+, VI-, VI, VI+, VI.1, VI.1+, VI.2, VI.2+, i tak dalej aż do VI.8.

16 Wspinanie „na wędkę” jest jednym z najbezpieczniejszych i najprostszych sposobów asekurowania wspinacza, czyli chronienia go przed konsekwencjami odpadnięcia. Polega on na przeciagnięciu liny wspinaczkowej przez wysoko 
pokonania drogi. Jest ubrany $w$ petna uprzaż dla dzieci. Asekuruje go ciocia, wujek doglada i podpowiada. Na kocu obok, w odległości około 4 metrów od skały siedzi mama $z$ tata $i$ z około półtorarocznym dzieckiem. Ja i mój partner wspinaczkowy stoimy w pobliżu czekając aż zwolni się droga, która wybraliśmy dla siebie do wspinania. $Z$ czasem orientujemy się, że to może potrwać dłużej niż sądziliśmy, bo cała rodzina chce się po kolei wspinać.

Opis sytuacji: Chłopiec przechodzi kawałek drogi, po czym mówi, $\dot{\boldsymbol{z} e}$ się boi. To jego pierwsza wspinaczka $w$ życiu. Tata, ciocia $i w u-$ jek uspokajaja go. Zachęcaja do dalszego wspinania. Wujek sugeruje cioci, żeby pokazała małemu jak wyglada zjazd - jak będzie zjeżdżał potem $z$ drogi. Chłopiec znowu mówi, że się boi. Tata mówi mu $\dot{z}$ eby się nie bat, że spokojnie zjedzie. Kilka osób mówi do chłopca na raz: ciocia, tata $i$ wujek. Doradzaja, co ma zrobić $i$ uspokajaja. Ciocia wreszcie przerywa to i prosi chłopca, aby sie skoncentrowat na tym, co ona do niego mówi, prosi żeby odchylit się do tyłu i usiadt w uprzęży. Wreszcie po kilku próbach chłopcu udaje się zjechać. Staje na ziemi. Ciocia mu wyjaśnia, że właśnie tak będzie zjeżdżał, kiedy zakończy droge, że to była taka próba i że teraz może wejść na drogę. "Acha, to jeszcze raz trzeba?” - chłopiec wzdycha, ale podejmuje próbę. Wchodzi drugi raz, dochodzi do trudniejszego miejsca, spoglada $w$ dót i mówi: „O jejku, a jak ja stad zejdę?” Jest wyraźnie zaniepokojony. Ciocia mówi żeby sie nie martwit, że zjedzie tak jak mu pokazywali. Tata zachęca, żeby wchodził wyżej. Wreszcie chłopiec mówi, że jeśli ma zjeżdżać to już woli pójść wyżej. Posuwa się do góry parę kroków. Dochodzi do trudniejszego miejsca, próbuje kilka razy złapać się czegoś, ale nie ma pomysłu i mówi, że chce już zejść. Rodzice i wujostwo kilkakrotnie zachęcaja go do wejścia, uspokajaja i podpowiadaja co ma zrobić, jak ma iść. Chłopiec kilkakrotnie powtarza, że chce zejść. Wreszcie ciocia zgadza się $i$ prosi o to żeby usiadł $w$ uprzęży $i$ odchylił się do tyłu. Tata mówi do niego: „Zjedź, a jak odpoczniesz, to wejdziesz drugi raz." Chłopiec jest zaniepokojony, „Ale jak ja spadnę?” - „Nie bój się, nie spadniesz, jesteś zawieszony na linie. Po prostu usiadź w uprzęży." Chłopiec pyta, czy może się złapać za linę. Ciocia mówi, że tak, nad węzłem. Chłopiec chwyta za węzeł. Ciocia go poprawia, mówi, żeby schwycił się liny nad węzłem. Chłopiec tak robi i kawałek zjeżdża, po czym obkręca się wokót osi liny i wykręca plecami do ściany. Interwencje podejmuje wujek, podchodzi do niego bez asekuracji po ścianie, staje za nim

\footnotetext{
umieszczony punkt asekuracyjny - zazwyczaj na szczycie drogi wspinaczkowej. W ten sposób wspinacz zabezpieczany jest liną biegnącą od góry, a w razie odpadnięcia zostaje zatrzymany na danej wysokości jak na wędce. Asekurujący hamuje ruch liny przy użyciu specjalnego urządzenia zaciskowego, a wspinacz bezpiecznie zawisa na linie w swojej uprzęży (por. Goddard, Neuman 1994).
} 
i pomaga mu przy zjeździe. Chłopiec szczęśliwy staje na ziemi. (notatka terenowa $z$ obserwacji uczestniczacej niejawnej ${ }^{17}, 6$ sierpnia 2009) ${ }^{18}$

Ośmio- czy dziewięcioletni chłopiec, przygotowujący się do swojej pierwszej w życiu wspinaczki wielokrotnie deklarował, że się boi i że chce zjechać na dół. Na przeżywane przez niego niepokój, podenerwowanie i lęk wskazywała wyraźnie jego ekspresja werbalna. Po pokonaniu kilku metrów wyraził swój lęk okrzykiem: „O jejku, a jak ja stąd zejdę?" oraz bardziej konkretna wizją negatywnych konsekwencji wspinaczki zawartym w pytaniu: „Ale jak ja spadnę?”. Kontynuował wspinanie pod łagodnym naciskiem rodziców i wujostwa. Ojciec i ciocia uspokajali go zapewnieniami: „Nie bój się, nie spadniesz, jesteś zawieszony na linie. Po prostu usiądź w uprzęży.”

${ }^{17} \mathrm{~W}$ rejonie skalnym jest zazwyczaj wiele ludzi. Przemieszczając się pomiędzy turniami co chwilę spotyka się wspinajacych i asekurujących oraz siedzących pod skałami w mniejszych lub większych grupkach. Przechodząc obok nich mówi się im "Cześć" i idzie dalej w stronę własnego celu wspinaczkowego. Ta naturalna sceneria sytuacji wspinania obejmuje kilkanaście lub nawet kilkadziesiąt rozmieszczonych w całym rejonie oraz przemieszczających się pomiędzy turniami zespołów. W takiej sytuacji trudno jest anonsować się jako badacz wszystkim napotkanym po drodze osobom, zwłaszcza, że większość z nich po prostu się mija nie obejmując bezpośrednią obserwacja. Dlatego w sytuacji przemieszczania się w rejonie skalnym nie ogłaszałam każdej napotkanej osobie, że prowadzę badanie na temat działalności wspinaczkowej. Byłoby to nie tylko dziwne i zaburzające naturalny przebieg wydarzeń, ale także po prostu niewykonalne. W całym prowadzonym przez siebie badaniu dokładałam wszelkich starań, by swoim informatorom, rozmówcom, obserwowanym oraz nagrywanym otwarcie prezentować siebie jako badacza. Za każdym razem, gdy podejmowałam rozmowę $z$ ludźmi przekazywałam informację, że prowadzę badanie na temat społecznego świata wspinaczki, ale w pewnych kontekstach sytuacyjnych było to po prostu niemożliwe. Po pierwsze, działo się tak wówczas, gdy uczestników obserwowanej sytuacji było zbyt wielu i niewykonalne było dotarcie do nich wszystkich $z$ ta informacją (zawody wspinaczkowe, spotkania dużych grup, sytuacje dynamiczne, w których członkowie nieustannie się zmieniali), po drugie, gdy w momencie zdarzenia, którego byłam uczestnikiem, ja sama nie zdawałam sobie sprawy z jego wagi dla dalszej pracy analitycznej. Tak było w opisanym Przypadku 1. W tamtej chwili nie pomyślałam nawet, że to, co widzę może być czymś istotnym dla mojego badania. Po prostu czekałam na „swoja kolejkę" pod drogą. Dopiero wieczorem, przygotowujac notatki terenowe $z$ obserwacji dokonanych tego dnia, zdałam sobie sprawę, że scena, której byłam uczestnikiem może być ważna dla zrozumienia tego, jak wspinacze radza sobie ze strachem - niestety zbyt późno, aby wyjaśnić obserwowanym, że prowadzę badanie dotyczące działalności wspinaczkowej.

18 Prezentowane fragmenty notatek terenowych oraz wywiadów podawane sa zgodnie $z$ ich oryginalnym brzmieniem. Cytaty $z$ wywiadów zawieraja zapis uwzględniajacy w transkrypcji: niedokończone słowa/, dłuższe chwile milczenia ( ), monosylaby oraz onomatopeje. 
Scena ta przykuła moją uwage, ponieważ przywołała $z$ pamięci moje własne początki wspinania i związany $z$ nimi lęk wysokości. Patrzac na tego chłopca myślałam sobie: Wiem, co czujesz, mały. Pamiętam, że w trakcie pierwszych wspinaczek pewna trudność stanowiło dla mnie to, by uwierzyć, że lina i uprząż są w stanie utrzymać ciężar mojego ciała i naprawdę ochronić mnie przed upadkiem. A jak się urwie? - myślałam - To koniec! - widzac, że powierzam całe swoje bezpieczeństwo linie i uprzęży. Początkowo było dla mnie również trudne do wyobrażenia, że niepozorna pętla $z$ taśmy ${ }^{19}$ przywiąana do uprzęży w połączeniu $z$ karabinkiem lub ekspresem ${ }^{20}$ wpiętym $\mathrm{w}$ punkt asekuracyjny może stanowić wystarczający punkt podparcia, dzięki któremu mogę się skutecznie autoasekurować i bezpiecznie zawisnąć nad przepaścią.

Już po kilku próbach nauczyłam się wypierać niepokojace obrazy rozerwanej uprzęży czy pękniętej liny i traktować te elementy jako pewne i dajace oparcie. To pomogło mi ostatecznie pokonać lęk przed ekspozycją, ponieważ nauczyłam się ufnie opierać na elementach wyposażenia wspinaczkowego. Na samym początku jednak - tak jak bohater opisanego przypadku - musiałam się nauczyć siadać w uprzęży. Aby obciążyć uprząż swoim ciężarem trzeba nieco wychylić się do tyłu i dosłownie usiąść w pasach udowych uprzęży, a to oznacza pokonanie lęku przed utrata stabilnej pozycji, wystawienie własnego ciała poza bezpieczną oś równowagi i zrezygnowanie $z$ dotychczasowych punktów oparcia, które zazwyczaj instynktownie staramy się utrzymać. Wspinacz musi się nauczyć, jak operować własnym ciałem w uprzęży nie tylko podczas zajmowania miejsca na stanowisku asekuracyjnym, ale także podczas zjazdów - bez względu na to, jaka wysokość dzieli go od ziemi i jaka otchłań roztacza się pod stopami.

Za sprawą tej krótkiej scenki, przywołując obraz chłopca, który miał problemy poczatkujaccego wspinacza podobne do moich

19 Takie profesjonalne taśmy wykonane $z$ dynemy lub poliamidu sa $\mathrm{w}$ stanie utrzymać obciążenia statyczne do dwóch ton i wytrzymuja próby rozerwania o sile $22 \mathrm{kN}$ (źródło: http://eu.blackdiamondequipment.com).

${ }^{20}$ Ekspres jest rodzajem sprzętu wspinaczkowego używanego do ochrony wspinacza podczas wspinaczki $z$ dolna asekuracją. Jest to narzędzie składające się $z$ dwóch karabinków połączonych mocną zszytą taśmą. Wspinacz wpina jeden karabinek ekspresu do punktu asekuracyjnego umieszczonego w skale, a drugi do liny, która za soba ciagnie, w ten sposób w miarę posuwania się w górę zapewnia sobie ochronę w najbliższym polu swojego działania. Jeśli odpadnie - zatrzymuje się na ostatnim wpiętym do systemu asekuracyjnego ekspresie. Ekspres wytrzymuje obciążenia $20 \mathrm{kN}$ ! (4496 lbf). 
własnych, zrozumiałam, czego wspinacz musi się nauczyć, jaki rodzaj doświadczenia cielesnego musi osiagnąć, by móc w ogóle zaczać się wspinać i wykonywać zjazdy oraz jakie emocje sa zasadniczą częścia tej fazy uczenia się wspinania ${ }^{21}$. Analiza tej sytuacji sprawiła, że zdałam sobie sprawę, że był czas, kiedy ja sama także doświadczałam przerażenia na widok wysokości, na której się znalazłam, a siadanie w uprzęży było dla mnie krótką, ale nieprzyjemna chwila zaryzykowania własnego poczucia bezpieczeństwa. To sprowokowało mnie by powrócić do moich notatek terenowych $z$ początków badania $-z$ czasów kursu wspinaczkowego. I rzeczywiście odnalazłam w nich pierwsze tropy dotyczące tych odczuć i emocji, które jednak dotąd nie zostały powiązane $z$ żadnymi innymi kategoriami i jako takie nie były włączone do analizy wyodrębnionych procesów społecznych. W moim dzienniku obserwacji pisałam m.in.:

Jest bardzo dużo rzeczy, których nigdy nie wyczytałabym z ksiażek. Ucieleśnione doświadczenie trudności drogi. Niepewności asekuracji. Niedowierzanie, że krótki kawałek liny może mnie pewnie utrzymać $w$ powietrzu... (dziennik obserwacji, 19 sierpnia 2007)

Chociaż w chwili prowadzenia obserwacji - zarówno w roku 2007 jak i później w 2009 - nie szukałam danych na temat lęku i strachu przeżywanego przez wspinaczy - tematyka ta wyłoniła się spontanicznie i rozwinęła jako znacząca część analizy sytuacji pierwszych doświadczeń wspinaczkowych oraz uczenia się wspinania.

To krótkie zaobserwowane przypadkiem zdarzenie naświetliło mi proces, który sama przeszłam, a który (dopiero teraz) nazwałam zdobywaniem zaufania do sprzętu wspinaczkowego. $\mathrm{Na}$ początku strach jest większy niż zaufanie do systemu asekuracyjnego (liny, uprzęży, przyrządów asekuracyjnych). W kolejnych próbach uczestnik decyduje się „zaufać” sprzętowi i zaczyna traktować elementy posiadanego wyposażenia jako zapewniające pełne bezpieczeństwo. Wówczas jako pewnik traktuje się własne przeświadczenie, że lina się nie zerwie, że poprawnie zawiązany węzeł nie rozwiąże się i będzie trzymał, że siedzenie w uprzęży jest bezpiecz-

${ }^{21}$ Oczywiście istnieją w tym względzie duże różnice indywidualne - ludzie reagują różnie na wysokość lub widok przepaści. Jedni nigdy nie są w stanie pokonać własnego lęku i paraliżuje on ich dalsze ruchy, inni nawet nie pamiętaja tej fazy własnego „wchodzenia do wspinania”. 
ne ${ }^{22}$. Nałożenie takiej definicji umożliwia zanurzenie się w działaniu wspinaczkowym i podjęcie właściwej nauki wspinania - rozwijania wspinaczkowych umiejętności i pokonanie lęku wysokości czy lęku przed ekspozycja.

W kolejnych latach prowadzonych badań wielokrotnie obserwowałam zbliżone sytuacje na komercyjnych ściankach wspinaczkowych, na które rodzice przyprowadzali swoje pociechy, aby spróbowały wspinania. Motyw lęku wysokości i lęku przed odpadnięciem był obecny w większości pierwszych prób wspinaczkowych ${ }^{23}$. W bardzo podobny sposób dzieci wspinające się po raz pierwszy reagowały na wysokość - po kilku metrach wspinania zatrzymywały się i nie były w stanie pójść wyżej, paraliżował je strach, lękały się, jak powróca na ziemię, wielokrotnie powtarzały, że chca już zejść i zakończyć wspinanie. W bardzo podobny sposób rodzice i asekurujący pracownicy ścianek reagowali werbalnie na taka sytuację

${ }^{22}$ Inną kwestia jest to, że sprzęt wspinaczkowy musi być poprawnie używany i przechowywany, a po pewnym czasie wycofywany z użytku. Nabieranie pewności co do możliwości wyposażenia wspinaczkowego i pokładanie w nim pełnego zaufania spowodowane wieloletnim doświadczeniem i rutyna w operacjach linowych i sprzętowych wystawia wspinacza na realne ryzyko i może być także przyczyna wypadków. Popełnienie małego błędu w operacjach sprzętowych przy zachowaniu pełnego zaufania do sprzętu - może kosztować życie. Historia wspinaczkowego świata opisuje bardzo wiele takich przypadków, w których wysokiej klasy wspinacz $z$ wieloletnim doświadczeniem ulega tragicznemu w skutkach wypadkowi z powodu zbytniego zaufania pokładanego w sprzęcie. Można tu wymienić przypadek śmierci amerykańskiego wspinacza Todda Skinnera (1958-2006), który podczas wspinaczki spadł $z$ dużej wysokości i zginął na miejscu, ponieważ $z$ powodu zużycia zerwał się wytarty kluczowy element jego uprzęży wspinaczkowej - łącznik uprzęży. Wspinacz od lat nosił tę samą stara uprzą̇̇, nie wycofał jej na czas z użycia, nadal definiował ja jako bezpieczna i zapewniająca oparcie. Taka pewność i pełne zaufanie do sprzętu nie eliminuje także niebezpieczeństwa popełnienia błędu w operacjach linowo-sprzętowych. Niezwykle uzdolniony 12-letni wspinacz włoski Tito Claudio Traversa (2001-2013), w trakcie wspinaczki „powierzył swoje życie" ekspresom, których użył w niepoprawny sposób, co spowodowało ich zerwanie i upadek $z$ dużej wysokości i śmierć (źródło: http://www.rockandice.com/lates-news / 12-year-old-tito-traversa-dies-in-climbing-fall; data dostępu: 06.07.2013).

${ }^{23}$ Nieco inaczej wygląda proces socjalizacji do wspinania w rodzinach wspinaczkowych, w których dzieci od najmłodszych lat towarzysza swoim „znaczacym innym” w aktywności skałkowej lub w treningu na ściance wspinaczkowej, obserwując wspinanie jako działanie zwyczajne i w sposób naturalny naśladując rodziców. Dotyczy to również dzieci uczestniczących w sekcjach wspinaczkowych dla juniorów, w których poprzez obserwację innych dzieci i wspólne działanie uczą się pokonywania ograniczeń własnego lęku wysokości i traktują nabieranie wysokości jako czynność naturalna. 
- negocjowali $z$ dzieckiem, by wykonało jeszcze jeden krok, usiłowali zapewnić je, że nadal jest bezpieczne, zachęcali by usiadło w uprzęży i sprawdziło, że wciąż jest przypięte do liny i nie spadnie, pokazywali, jak będzie wyglądał zjazd i zachęcali do pokonania strachu.

Śledzenie emocjonalnych aspektów aktywności wspinaczkowej rozpoczęło się w moim badaniu od dokonania przypadkowej obserwacji terenowej, która natychmiast odniosłam do swoich własnych ucieleśnionych doświadczeń. Trudno przesądzić, czy gdybym ich nie posiadała równie interesujący wydałby mi się akt zmagania chłopca $z$ lękiem przed wysokością. Ciekawe jest jednak także i to, że dopiero zderzenie moich własnych zapamiętanych odczuć $z$ unaocznieniem podobnych emocji zaobserwowanych u kogoś innego - uchwyconych w jego werbalnych i niewerbalnych formach ekspresji - dało mi szansę na podjęcie tego tropu i dalsze pogłębione poszukiwania.

\section{Autoetnografia}

Zaczęłam zastanawiać się nad tym, jak ja sama radziłam sobie ze strachem oraz lękiem wysokości i przywoływałam $z$ pamięci oraz $z$ notatek terenowych sytuacje i zdarzenia, w których tematy te były obecne i odgrywały ważna rolę podczas wspinania. Moje pierwsze głębokie doświadczenie $z$ tymi odczuciami miało miejsce już czwartego dnia kursu wspinaczkowego.

Przypadek 2. Moja instruktorka wysłała mnie do poprowadzenia dro$g^{24}$ biegnacej przez parometrowy komin, co wymuszało posuwanie sie w góre poprzez zapieranie się nogami i plecami o ściany komina, a nastepnie przejście ponad jego światłem, wyjście z jego prawej strony na lewa do punktu asekuracyjnego, by następnie ponownie przekroczyć

${ }^{24}$ Prowadzenie drogi (ang. lead climbing) polega na pokonywaniu drogi wspinaczkowej $z$ dolna asekuracją (nie jak w przypadku „wędki”, w której lina asekuracyjna biegnie do wspinacza $z$ góry). Oznacza to, że cały system asekuracji umiejscowiony jest poniżej wspinacza. Na dole stoi jego partner i wydaje mu linę, a wspinacz wpina ją ekspresami do napotykanych po drodze punktów asekuracyjnych. Bezpieczeństwo uzyskiwane podczas tego typu wspinania zależy zarówno od umiejętności prowadzacego (wykonywania przez niego poprawnych wpinek), jak i asekurującego, który wydaje linę i umiejętnie wyhamowuje ją w razie odpadnięcia partnera. 
ziejacy otwór i dostać się do stanowiska zjazdowego znajdujacego się powyżej po prawej stronie.

Poczatkowe kroki wykonałam niejako z rozpędu, ale na wysokości wejścia do komina zaczęłam odczuwać paniczny strach. W istocie nie wierzyłam, że uda mi sie poprowadzić tę droge, a w głowie dzwoniła wcią̇ myśl niedowierzania, że moja instruktorka mogła posłać mnie na tak trudna drogę. Ona sama stała poniżej i spokojnym, nieco znudzonym głosem podpowiadała mi jak iść. Posuwałam się właściwie, wyłacznie dlatego, że $w$ jej postawie i głosie wyczuwałam taka pewność $i$ oczywistość tego, że przejde droge, że nie miałam innego wyjścia niż próbować. Prowadzaca kurs nie zdradzała najmniejszych objawów niepokoju o mnie - co najwyżej odrobinę niecierpliwości z powodu mojego ślimaczego tempa.

Dodatkowym czynnikiem potegujacym mój strach był fakt, że było to moje pierwsze prowadzenie drogi, a $w$ dodatku zabrałam ze soba za mało ekspresów - zabrakło mi dwóch do ostatnich wpinek. Było bardzo goraco. Popełniałam jeden bład za drugim z poczuciem, że nie mam wystarczajacej asekuracji. Utknęłam. Byłam tak przerażona, że całe moje ciało się trzęsło jak galareta. Moje ręce drżały, ciało $w$ catkowitym napięciu. Bałam sie wykonać kolejnego ruchu, a doznania te graniczyły z walka o życie. Nie wiedziałam co robić. Byłam zdezorientowana. W głowie miałam pustkę. Nie mogłam zebrać myśli ani podjać

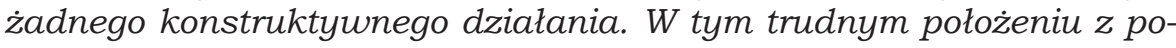
moca przyszedł mi kolega kursowy - Daniel.

Daniel doszedł łatwiejsza ścieżka do punktu, $w$ którym utknęłam $i$ podał mi brakujacy sprzęt. Niewiele to dało, bo byłam całkowicie "rozbita" i niezdolna do sensownego działania. Widzac to pomógł mi sie przewiazać na stanowisku i przygotował mnie do zjazdu. Byłam na skraju łez. Jedyna myśla, jaka kołatała mi się $w$ głowie było to, że nie wierze, że to sie dzieje naprawdę. Miałam poczucie nierzeczywistości całej tej sytuacji, jakby mnie tam nie było. Odczuwałam wyłacznie paraliżujacy strach, że spadne $w$ dót $i$ to będzie koniec. (zapis autoetnograficzny ex-post, 2 marca 2011)

Przez cztery lata nie umiałam odnieść się analitycznie do tego doświadczenia, ani umiejscowić go w sieci generowanych kategorii. Powróciłam do niego dopiero w 2011 roku analizując emocje strachu i lęku przeżywanego przez wspinaczy. Przyglądając się tej sytuacji „na chłodno” i z dystansu, widząc w niej przypadek doznań początkującego wspinacza, dostrzegłam, jak bardzo pouczające były dla mnie przeżycia związane $z$ doświadczaniem strachu i paniki oraz z sytuacyjnym kontekstem ich wyrażania. Uzmysłowiłam sobie, że ten wstrząsający incydent, dzięki zderzeniu $z$ zachowaniami innych osób, wyposażył mnie wtedy w nową perspektywę 
poznawcza dotycząca wspinania, która zaważyła na mojej dalszej działalności wspinaczkowej.

Przede wszystkim, po tym jak stanęłam na ziemi, odkryłam, że możliwe są odmienne niż mój własny sposoby reagowania na sytuację subiektywnej trudności drogi. W samokontroli i opanowaniu Daniela, w spokoju mojej instruktorki ujrzałam inne od swoich własnych formy reakcji. $Z$ ich zachowań mogłam dowiedzieć się także, że właśnie te inne formy spotykaja się z aprobatą. Zobaczyłam, że instruktorka nie „zaraziła się” moim strachem, co było dla mnie bardzo czytelnym komunikatem, mieszczacym się w kategoriach informacyjnego wpływu społecznego, że sytuacja jest pod kontrola i że nie ma potrzeby doświadczać aż tak skrajnych emocji („nie ma powodu żeby się aż tak bać"). Było to $z$ pewnościa związane $z$ pozycją instruktora, którego opinia w trakcie kursu wspinaczkowego ma charakter wiążący. To jego/jej definicja sytuacji jest w tym kontekście „prawidłowa” i „poprawna”, a nie definicja adepta.

Kiedy więc zjechałam na dół, byłam zawstydzona moim "występem” $i$ miałam poczucie kompletnej porażki. Moja instruktorka $z$ kolei wyraziła zaskoczenie $-z$ niedowierzaniem zapytała mnie: „Ania, ty sie naprawdę bałaś?”. Cała reszte dnia po tym wydarzeniu gniotło mnie poczucie niepowodzenia i własnej nieudolności.

Dodatkowo moja ulga, gdy stanęłam na ziemi raptownie rozpłynęła sie po komentarzach dwóch innych wspinaczy, którzy przyszli sie wspinać na drodze z kominem. Jeden $z$ nich wyjaśniał drugiemu, że jest to bardzo prosta droga, wyceniona na III+, która zazwyczaj pokonywana jest jedynie dla jej wartości estetycznej. Tymczasem $w$ moim odczuciu była to najtrudniejsza rzecz, jaka kiedykolwiek usiłowałam zrobić. Było to dla mnie druzgoczace. Czułam sie fatalnie. (ciag dalszy zapisu autoetnograficznego ex-post; 2 marca 2011)

Te nieprzyjemne emocje $z$ pewnościa później demotywowały mnie do powtórzenia podobnej sceny i poddawania się panice w chwili wspinania. Nie umiałam wówczas nazwać tych wewnętrznych procesów, ale musiałam chyba już wtedy zdać sobie sprawę, że wpadanie $\mathrm{w}$ panikę nie jest aprobowana reakcja na strach doświadczany w sytuacji wspinania. I w jakiś sposób wyparłam ten rodzaj reagowania jako niestosowny. Nie oznacza to, że już nigdy więcej nie doświadczyłam takich emocji. Jednakże już nigdy w taki sposób nie poddałam się przerażeniu. Nauczyłam się reagować na nie inaczej: złością, przeklinaniem, krzykami, ale nie panika i dezorientacją. Podczas następnych dni kursu atakowałam bez zawahania drogi wskazane przez moja instruktorkę. Dla mnie samej było 
to zaskakujące, że jednego dnia tak strasznie się bałam i byłam przerażona, a następnego kompletnie odrzuciłam tę formę reakcji. Było w tym coś z dokonywania wyboru „poprawnego" i oczekiwanego przez innych sposobu zachowania.

$\mathrm{Na}$ tę zmianę nałożył się także toczący się w naszych (adeptów) umysłach - proces redefiniowania zagrożen wspinaczkowych, który przebiegał stopniowo i niemal niezauważalnie, ale wyraźnie kształtował nasze wyobrażenie o tym, co jest bezpieczne i niebezpieczne podczas wspinania i pozwalał przedefiniować sytuacje rodzące lęk wysokości. Na proces ten składało się wiele drobnych epizodów oraz obserwacji dokonywanych przez nas na bieżąco. $\mathrm{Na}$ przykład, widok instruktorów wspinających się na najwyższe fragmenty dróg kursowych w zwykłych trampkach i bez żadnego zabezpieczenia. Tam, gdzie adept „walczył o życie” - instruktor pokonywał drogę bez najmniejszego wysiłku, poruszając się płynnie, estetycznie, lekko i często bez asekuracji. Było wiele takich sytuacji. Początkowo było to szokujące i stało w wyraźnym kontraście $z$ pełnym wyposażeniem kursantów - noszacych uprzęże, buty wspinaczkowe oraz kaski $-z$ czasem jednak stało się zwyczajnym obrazem, traktowanym przez nas jako coś oczywistego. Kręciliśmy ze zdumienia głowami, widząc instruktora w sandałach i $z$ dużym plecakiem na plecach pokonującego bez asekuracji droge piątkowa, ale w tym samym momencie przyzwyczajaliśmy się do takiego widoku i tego rodzaju sceny zaczynaliśmy traktować jako „normalny” element wspinaczkowych sytuacji. W rezultacie - poza wyrażanym wciąż przez nas podziwem dla takich wyczynów, poza świadomością własnej słabości i „niedorastania” do maestrii instruktorów - niezauważalnie zmienialiśmy naszą percepcję tych sytuacji, normalizując je i przywykając do nich.

Miało to dalsze konsekwencje dla naszych przekonań o tym, co jest możliwe w skałach i gdzie leży niewidzialna granica pomiędzy bezpieczeństwem a zagrożeniem. To $z$ kolei obniżało nasza skłonność do reagowania strachem w sytuacjach działania na dużej wysokości oraz w ekspozycji. Obserwowanie innych kursantów posłusznie wspinających się na wskazane przez instruktorów drogi i przechodzących trudne miejsca oraz obserwowanie zachowań doświadczonych wspinaczy - wszystko to wytwarzało atmosferę akceptacji dla ryzyka związanego $z$ nabieraniem wysokości i kształtowało nasz ogląd „normalnych” i „prawidłowych” zachowań wspinaczkowych. W tym szczególnym kontekście stawało się dla nas jasne, że „poprawnym” sposobem reagowania jest mierzenie się $z$ wlasnym strachem i nie uleganie panice. 
To, co dzieje się podczas kursu wspinaczkowego jest zderzeniem dwóch koncepcji: nowicjusza - dla którego aktywność wspinaczkowa jest niezwykle trudna i wymagająca, a drogi niemal „niemożliwe do przejścia" - oraz instruktora, według którego kursant pokonuje banalnie prostą drogę ${ }^{25}$. Jest to również zderzenie oceny własnych możliwości i kompetencji adepta $-z$ opiniami instruktora na temat umiejętności nowicjusza. I wreszcie, jest to także zderzenie sposobu percepcji przestrzeni, w której prowadzi się działanie w dwóch momentach czasowych - sprzed i po przejściu drogi. Droga, która tuż przed rozpoczęciem wspinania wydaje się niedostępną pionową ściana $-z$ mienia się po pomyślnym jej pokonaniu w tę, która „udało mi się przejść" - zmianie ulega więc także autodefinicja samego adepta.

Zderzenie perspektywy kursanta - dla którego wejście było „walką o życie” i który właśnie „wykonał najtrudniejsza i najbardziej niebezpieczną rzecz w swoim życiu" (jak pokonanie paniki, działanie pomimo strachu) $-z$ perspektywa doświadczonych wspinaczy, dla których droga wyceniona była na III+, miała charakter rekreacyjny lub była po prostu ciekawym punktem widokowym - jest druzgoczace dla definicji sytuacji tworzonych przez nowicjusza. Musi on poddać swoją definicję sytuacji rewizji i uznać ją za nieadekwatna. Jako obowiąująca przyjmuje obraz zdarzenia podsuwany przez doświadczonych wspinaczy i zaczyna oceniać swoje własne osiagnięcie w inny sposób niż podpowiada mu jego własna percepcja. Słyszac, że to, co zrobił ma niską wycenę, nabiera też ochoty na podniesienie własnego poziomu i spróbowanie trudniejszych - bardziej docenianych przez innych wspinaczy dróg.

Patrząc $z$ dystansu na mój własny proces wchodzenia do świata wspinania widzę, że swój poziom umiejętności wspinaczkowych

25 Te znaczące różnice możliwe są do zaobserwowania podczas większości kursów wspinaczkowych. Odzwierciedla je m.in. następujacy fragment moich notatek terenowych: „Ja i mój partner wspinaczkowy obserwujemy jak wspina się grupa kursowa $z$ Wrocławia. Prowadząc drogę kursanci dochodzą do pewnego punktu, którego dalej nie moga już przejść. Po kilku takich próbach instruktor sam zakłada buty i asekurowany przez jedną $z$ kursantek bez trudu pokonuje drogę. Widzę ogromną różnicę we wspinaniu instruktora i kursantów. Jego ruchy sa powolne, bardzo płynne, ręce bezbłędnie trafiają w chwyty, jakby znały je na pamięć, niczego nie szukaja, ruchy sa pewne, ciało balansuje, przegina się, prawie tańczy na skalnej ścianie. Wygląda jakby płyną. Posuwa się w górę kompletnie bezwysiłkowo. Pięknie. Z gracją. Kursanci wchodzą $z$ wyraźnym trudem, czerwienieją od wysiłku, sapią, popełniają błędy w ocenie swoich możliwości balansu. Sa spięci, trzęsą się. Chwytają się ściany kurczowo. Widać, że boją się odpaść. Przed każdym chwytem kilkakrotnie dotykaja ściany w kilku różnych miejscach, próbując ocenić, czego da się złapać" (źródło: notatka terenowa, Góry Sokole, 6 sierpnia 2009). 
uczyłam się oszacowywać opierając się właśnie na wypowiedziach innych, bardziej doświadczonych wspinaczy, którzy posługiwali się funkcjonujacymi w środowisku systemami wycen dróg skalnych oraz powiazanymi $z$ tym sposobami wartościowania dokonań wspinaczkowych. Dostrzegam też (dopiero teraz!), jak bezkrytycznie przyjmowałam te zewnętrzne źródła oszacowań. Świadczy o tym komentarz zawarty $\mathrm{w}$ moim dzienniku obserwacji $z$ pierwszego kursu wspinaczkowego, w którym pod koniec dnia wspinaczkowego relacjonuję: "Ostatecznie zrobiłam tylko dwie marne trójki”"26 - co oznaczało, że tego dnia udało mi się przejść jedynie dwie drogi o wycenie III. To krótkie zdanie dokumentuje to, jak łatwo przyjęłam perspektywę bardziej doświadczonych wspinaczy do oszacowywania swojej własnej aktywności i jak ta perspektywa niemal od samego początku napędzała moja ambicję robienia trudniejszych dróg. Jedynym kosztem, jaki musiałam ponieść było odrzucenie mojej własnej perspektywy i mojej własnej prawdy opisującej osobiste autentyczne doznania: „Walczyłam o życie”, „Tak bardzo się bałam”, „Paraliżował mnie strach przed odpadnięciem”, „Było bardzo trudno”, „Bałam się, że zrobię sobie krzywdę”.

Tak więc, równolegle do procesu uczenia się, jak się wspinać i jak czynić wspinanie bezpiecznym przy użyciu wspinaczkowej technologii mój kontakt ze wspinaczką skalną w niezauważalny dla mnie samej sposób stał się praca nad redefinicja strachu. Owa redefinicja oznaczała $z$ jednej strony odczytanie na nowo zagrożeń sytuacji wspinania - zgodnie $z$ perspektywa znaczacych innych. $Z$ drugiej ujawniała się jako aktywne zmaganie się $z$ własnym strachem jako emocją, która może czynić wspinanie jeszcze trudniejszym. Zorientowałam się, że mogę reagować na strach w inny sposób, a te nowe sposoby reakcji „podsuwali” mi znaczacy inni - bardziej doświadczeni koledzy oraz wspinaczkowi instruktorzy.

Chociaż tematy: zagrożeń we wspinaniu oraz definicji niebezpieczeństwa, podejmowania ryzyka, radzenia sobie $z$ lękiem wysokości oraz ze strachem $\mathrm{w}$ trakcie wspinania, związane $z$ ucieleśnionymi doświadczeniami (moimi własnymi oraz innych wspinaczy) przewijały się w moim badaniu od samego początku - ich właściwa interpretacja możliwa była dopiero po paru latach od ich doświadczenia i dokonania zapisu tych zdarzeń. Opracowanie i analiza emocjonalnych aspektów wspinania stały się możliwe $z$ dystansu, gdy ujrzałam je w szerszym kontekście i umiejscowiłam osobiste niepowtarzalne doświadczenia w polu zdarzeń należących do konkretnych

26 Źródło: notatka z dziennika obserwacji z dnia 21 sierpnia 2007. 
typów sytuacji: kursu wspinaczkowego, bycia początkującym wspinaczem, osoba aspirująca do podjęcia działań wspinaczkowych i starająca się przyjąc perspektywę grupy, do której pragnie należeć ${ }^{27}$. Główny problem nie polegał tu więc wyłącznie na tym, by ucieleśnione doświadczenie umieć nazwać i zamienić w tekst, ale aby zrozumieć je na tle innych zjawisk i umieścić w szerszej perspektywie (Clifford 1986: 2) - by przekroczyć konkretny opis i odnaleźć obecne w nim ogólne procesy społeczne (ang. generic social processes) (Prus 1996: 142).

Ważną rolę w „odkodowaniu” znaczeń moich własnych autonarracji odegrało uświadomienie sobie powszechności doznań strachu oraz lęku wśród adeptów wspinania. Nie byłabym skłonna potraktować moich osobistych doświadczeń jako czegoś wyjątkowego, unikalnego czy nawet wartego publicznej „wiwisekcji”, gdybym nie podejrzewała, że inni wspinacze moga odczuwać w podobny do mnie sposób i przechodzić te same procesy redefiniowania strachu. Kiedy napotkałam przypadki świadczące o tym, że inni doświadczają zbliżonych emocji, zaczęłam gromadzić ewidencje podobnych przypadków, sytuacji, działań oraz odczuć, by przyjrzeć się im bliżej.

\section{Wywiady oraz narracje wspinaczy}

Rozpoczęłam od poszukiwania wątków strachu oraz lęku w przeprowadzonych przeze mnie wywiadach ze wspinaczami. Okazało się, że niemal każdy wywiad ujawnia chwile przeżywanego stra-

27 Podobny proces odroczonego w czasie zapisu zdarzeń oraz ich analizy relacjonuje Susan Brownell w swoim tekście pt. Sport ethnography. A personal account (2006). Autorka opisując swoja trzyletnią etnografię w Chinach, realizowana $z$ pozycji mistrzyni świata $\mathrm{w}$ biegach wspomina, że będąc zaangażowana w proces treningowy jako „pełny uczestnik”, a następnie w sam udział w mistrzostwach, nie była w stanie robić szczegółowych notatek terenowych, ani potem nie była w stanie zmusić się do zapisania czegokolwiek jeszcze przez kilka miesięcy po powrocie do Stanów Zjednoczonych (Brownell 2006: 251). Uczestnictwo w działalności sportowej, zwłaszcza na wysokim poziomie, wymaga całkowitego zaangażowania i pełnego oddania działalności sportowej, która odbywa się „tu i teraz”, w danej chwili, toteż zamiana tych doświadczeń w naukowa analize "pociaga za soba niemal bolesny proces odseparowania się (detachment) od nich” (Tamże: 252). Autorka pisze, że dopiero kilka miesięcy po powrocie $z$ mistrzostw była w stanie zdystansować się do własnych doświadczeń i zaczać je opisywać. W moim przypadku - pierwsze zapisy pojawiaja się w dziennikach obserwacji oraz luźnych notatkach terenowych, ale ich właściwa interpretacja nie jest możliwa od razu - a dopiero po czasie i $z$ dystansu. 
chu lub przerażenia podczas działalności wspinaczkowej. Wspinacze w swoich opowieściach relacjonowali liczne sytuacje tego typu, wskazywali postrzegane przyczyny doświadczanego strachu oraz konteksty sytuacyjne uzasadniające strach, dostarczali opisu emocji oraz odczuć własnego ciała podczas ich przeżywania, a także opisywali ich wpływ na przebieg wspinaczki. Jedna $z$ badanych nakreśliła następujący obraz odczuwanego przez siebie strachu:

[P]o pierwsze, to, co jest ważne - to psychika. Mocne, mocne nerwy i to, żeby nie dostawać trzęsawki, bo ja na przykład jak zaczynam się bać, zaczyna mi się trzaść całe ciało. To nie jest zwykły telegraf w tydce, tylko y, serce mi strasznie zaczyna bić, zaczynam panikować. A jak zaczynam panikować, to trzęsa mi się ręce, gorzej się chwytam. No to jeszcze bardziej sie przyczepiam tymi łapami do tej skały i jeszcze bardziej sie przez to mecze. Stoję $w$ tym miejscu, nie moge się ruszyć. Boje się, boje się, boje się, boje, boje się, boję, boje się. Albo jest blok, albo ide dalej $i$ odpadne i jestem zła, czy coś $w$ tym stylu. Ale to jest, to jest myślę, że najważniejsze, żeby jednak się nie dać zjeść tym nerwom. I... to jest to, czego mi brakuje... W moim wspinaniu. Że jednaak noo, moja głowa we wspinaniu nie pracuje tak, jak powinna, no, że ja po prostu się często boję. (kobieta 25 lat, wspina się od 1,5 roku)

Inna badana, zapytana przeze mnie podczas wywiadu, co było najtrudniejszego w jej procesie uczenia się wspinania stwierdziła:

Cały czas jest trudne. Strach przed lataniem. Ja nie..., ja sie boje $w$ ogóle odpaść od od ściany. Zdarzyło mi się to ostatnio jak byliśmy miesiac temu właśnie pod Olsztynem to odpadłam z chwytem. Skała mi się oderwała [śmieje się]. (kobieta 32 lata, wspina się od 2,5 roku)

Nieco bardziej otwarcie i spontanicznie o własnym strachu i pracy nad nim opowiadały osoby $z$ mniejszym stażem wspinaczkowym. Ale również bardziej doświadczeni wspinacze, zapytani o emocje towarzyszace im podczas wspinania, wskazywali na doświadczany przez siebie lęk i strach:

AK: Jakie emocje ci towarzysza podczas wspinania?

Badany: Żadne. Czasami się boję.

AK: Powiedz mi o tym troche - o tym czego sie boisz.

Badany: Że dupe sttukę. Tu nie ma nic poza tym. No, to o to chodzi. O integralność cielesna. Chyba o to chodzi. Skutki sa... Czasami wiem, $\dot{z} e$ ten ruch jest bardziej ryzykowny i jak się nie uda to może się skończyć rozlewem krwi, no $i$ wtedy jest przykro, głupio, no. Wyjęte kilka miesięcy z funkcjonowania, coś tam... cała masa różnych - nie wia- 
domo jakie skutki końcowe. To sa... Wchodzimy $w$ świat nieprzewidywalnego - kompletnie. Tak, że tutaj to chyba o to chodzi tylko, że sie... że mam taki lęk przed yyy... Kiedyś miałem wypadek, złamałem noge $i$ to nie było nic przyjemnego $i$ chyba przypomina mi się... A, już wiem jaki jest ten moment! Dobre pytanie. Dobrze, że powiedziałem o tym wypadku. Zanim fiknałem wtedy i złamałem noge to byt taki moment jakiejś takiej, kurde, ( ) Twoja wola chce. I cały ty sam chcesz i chcesz, ale już dalej nie możesz. I to jest dosyć obrzydliwy moment, $w$ którym praktycznie rzecz biorac - chcac - nie jesteś $w$ stanie kontrolować nawet tego metra kwadratowego, który jest przestrzenia dla twoich (...) stóp i rakk. I to jest dosyć przykre odczucie. Tym bardziej jeśli jest połaczone $z$ momentem, kiedy ci odmawia sprawność posłuszeństwa. Że już dalej nie masz siły trzymać równowagi czy chwytów, czy ustać na stopniu i po prostu zaczynasz być po prostu takim workiem troche, który przypadkowo i znienacka odpada. To bardzo nieprzyjemne wrażenie. $Z$ czasem się nauczyłem tego, że się nie dochodzi do tego momentu tylko się odpowiednio wcześnie odpada [śmieje się] (...) albo wycofuje. (mężczyzna 55 lat, alpinista, taternik, wspina się od 37 lat)

Panikę opisywano jako emocję, która jest przeciwieństwem skutecznego działania:

[W] jednej chwili z osoby, która kontroluje otoczenie $i$ samego siebie, zamieniasz sie $w$ ofiare, kurczę, niemożności dalszej... niemożności kontrolowania otoczenia. A nawet ty sam nie jesteś $w$ stanie wydać polecenia swoim mięśniom, żeby dalej pracowały jak maja pracowaćpo prostu one już nie moga pracować. (...) I jeśli miałbym powiedzieć, że coś $w$ górach jest nieprzyjemnego - to taki właśnie moment - jak już sie doprowadzasz do momentu, $w$ którym nic już nie działa tak jak jesteś do tego przyzwyczajony: ani ręce, ani nogi, ani twoje poczucie równowagi. Czujesz jak wpadasz $\boldsymbol{w}$ panike, wiesz, że to się za chwile skończy tak, a nie inaczej-musi po prostu - a... (...) Szczególnie zima to jest przykre, bo wiadomo, że to jest dosyć... że to sie nie może bezkarnie skończyć. W większości wypadków... zima $w$ takiej sytuacji sa zwiazane z jakimiś obrażeniami. (...) Panika jest wewnątrz. To nie jest panika, która sie objawia nadpobudliwościa. To raczej jest stan niepokoju $w$ glowie. Tu jest panika. (...) chodzi o zinterioryzowana taka panikę, w której... (...) myśli 150 na sekundę $i$ żadna nie jest poprawna, żadnej nie potrafimy skonsumować. O taki stan chodzi. To nie jest stan jakby jakiegoś szarpania się tylko raczej niepokoju w głowie. (mężczyzna 55 lat, alpinista, taternik, wspina się od 37 lat)

Starsi stażem wspinacze podkreślali, że strach jest elementem paraliżującym i wykluczającym działanie. Często też przedstawiali 
wspinanie jako aktywność, która w swej istocie nie ma lub nie powinna mieć nic wspólnego $z$ emocjami:

No, każdy odczuwa strach na jakimś tam poziomie. To ważne żeby ten strach no nie był silniejszy od chęci wejścia na górę. Bo wtedy no kończymy. (mężczyzna 41 lat, wspinacz sportowy, instruktor PZA, wspina się od 26 lat)

[Wspinanie - przyp. AK] to dla mnie to jest moment kiedy jestem zamk/ skoncentrowany na, na tym, na przechwycie, na ruchu, to tutaj nie ma miejsca na emocje. (...) Tutaj jest jakiś program. E, e, który nie ma emocji. Nie powinien $w$ każdym razie mieć emocji, a jak się zaczynaja emocje, to mówimy o tym stanie [paniki - przyp. AK], który (...) jest na pograniczu odporności i fizycznej i psychicznej. To wtedy sie owszem emocje uruchamiaja. Natomiast dopóki wszystko idzie jak należy, to tam nie ma żadnych emocji. Jest koncentracja, jest uwaga, jest nastuchiwanie, obserwowanie, rozpo/, czytanie ściany y, y, y, no cała masa różnych operacji, które maja raczej charakter intelektualny y, $y$, y, percepcyjny. Przełożyć to trzeba na jakieś ruchy mięśniowo-kostne... To jest taki stan. Oczywiście te pozytywne emocje to sa momenty kiedy sie zapala papierosa na stanowisku, to sa momenty, kiedy sie kończy droge, kiedy się $z$ watpliwej pogody robi lepsza pogoda $i$ nagle coś, co było niewidoczne - zaczyna być widoczne, a my mamy za soba już fajny kawakek wspinania. To - to sa fajne momenty. Bez watpienia. I to sa pozytywne emocje. Tylko one nie sa... [częścia - przyp. AK] dziatania - o to chodzi. Działanie tutaj... Nie, nie, nie. Samo wspinanie, sam akt wspinania nie ma nic wspólnego $z$ emocjami. Tak bym to ująt. (mężczyzna 55 lat, alpinista, taternik, wspina się od 37 lat)

Poza trzydziestoma przeprowadzonymi wywiadami ze wspinaczami, analizowałam także wypowiedzi wspinaczy zawarte w wywiadach medialnych (magazynach wspinaczkowych, prasie ogólnopolskiej, telewizji, Internecie), a także na blogach wspinaczy, poszukując w nich wątków związanych $z$ tematem przeżywanego strachu. Profesjonalna wspinaczka amerykańska Steph Davis podczas jednego $z$ wywiadów na pytanie: „Jak ty sama radzisz sobie ze swoim strachem?", odpowiedziała:

Strach jest trudny, ponieważ, kiedy naprawde się boisz, to rzeczywiście nie możesz nic zrobić. I dlatego wkładam mnóstwo mojej energii $w$ studiowanie [własnego strachu - przyp. AK] i powiedzenie sobie: "Okay, to nie może mnie kontrolować”. Ponieważ strach po prostu niszczy wydajność (performance destroyer). I bycie przerażonym sprawia, że jesteś mniej bezpieczny, ponieważ nie możesz wykonać zadania. 
Więc staram sie naprawde mocno, by strach mnie nie zatrzymywat (not be stopped by my fear), ale także próbuje - teraz próbuje robić rzeczy nie dlatego, że się ich boję. Myślę, że gdy byłam młodsza, jeśli coś mnie przerażało, myślałam: „O, muszę to zrobić!”. Wiesz, chwycić byka za rogi $i$ zrealizować. Teraz, czasami, jeśli naprawde sie boje, wsłuchuje się w to i mówię: „Mmm, może nie dzisiaj”. (wywiad ze Steph Davis, uprawiająca wspinaczkę, skoki BASE oraz wingsuit - „Outside Today", 8 maja 2012, tekst dostępny pod adresem: http:/ /www. youtube.com/watch?v=FKYXPYqmvfg; data dostępu: 15.01.2014; tłum. własne - A.K.)

W innym wywiadzie Davis opisała, jak pracuje $z$ własnym strachem:

(...) istnieje dobry strach i zły strach. Zły strach jest (...) czymś, co sprawia, że działasz źle, nawet jeśli nie powinieneś. (...) I jest dobry strach doświadczany $w$ górach na przykład podczas zejścia lawiny. (...) To jest dobry strach. Powinieneś go słuchać. Chodzi o przetrwanie (for survival). Miałam kiedyś takie doświadczenie podczas jednej wspinaczki na żywca ${ }^{28}$ naprawde się przestraszyłam, $w$ głowie miałam tylko myśl: "Spadnę". Było naprawdę źle. Po tym doświadczeniu zdecydowałam, że... trzeba to kontrolować. Nie możesz nawet wyjść na wspinanie bez liny, jeśli coś takiego miałoby się zdarzyć. Ponieważ to może spowodować, że spadniesz. Bo możesz być perfekcyjnie przygotowany, ale jeśli zostaniesz zdominowany przez strach - on może być tym, co cię zabije. Myślę, że czasami to, co wkładasz do głowy jest tym, co pozostaje $w$ głowie. To wszystko dotyczy kontrolowania umysłu oraz wkładania do niego tego, co chcesz w nim mieć, a nie dopuszczania rzeczy, których nie chcesz. Na tym polega rysa (cracks) życia. (wywiad ze Steph Davis: High Infatuation with Steph Davis - „Health Beauty Life The Show", 24 maja 2012; tekst dostępny pod adresem: http://www.youtube.com/watch?v=7jNsMDoYK2g; data dostępu: 15.01.2014; tłum. własne - A.K.)

Również inne dane zastane, takie jak blogi czy narracje wspinaczy, wydają się potwierdzać wagę strachu w działalności wspinaczkowej. Steph Davis, opisujac własne zmagania ze strachem przywołuje sytuację, w której, gdy raz bała się podczas jednej ze swoich wspinaczek - zdecydowała się powtórzyć to wejście po to,

28 Wspinaczka „na żywca”, inaczej free solo oznacza, że wspinacz przemieszcza się po skale w stylu klasycznym, a więc wyłącznie przy użyciu siły własnych mięśni - bez wspomagania się sztucznymi ułatwieniami w rodzaju ławeczek czy pętli, ale także bez jakichkolwiek zabezpieczeń czy systemów asekuracyjnych (bez liny, uprzęży oraz partnera). 
aby zrealizować je w stanie wolnym od strachu (do it „unafraid”). Relacjonuje ona, że musi nieustannie pracować, by pokonywać własny strach:

Ja zawsze mierze się ze strachem. Więc czasami jestem w stanie osiagnać punkt, w którym przeszkadza mi on tak mało, że wcale go nie zauważam. Innym razem, naprawde czuje go i pracuje, żeby nie dać mu sie kontrolować $i$ to jest chyba najbardziej użyteczna umiejętność $w$ praktykowaniu [wspinaczki - przyp. A.K.], ponieważ zawsze będa momenty, kiedy będziesz sie bat, a mimo to będziesz musial kontynuować. (...) Myślę, że wolność nie wynika $z$ tego, że nigdy nie czuje sie strachu, ale z uczenia sie, jak robić rzeczy, które chcesz robić, nawet $w$ jego obecności, i jak robić je dobrze - a nie być powstrzymywanym przez niego. To jest prawdziwa wolność. (tekst dostępny pod adresem: http://www.highinfatuation.com/blog/survival-signals/; data dostępu: 15.01.2014; tłum. własne - A.K.)

Zatem nawet wysokiej klasy wspinacze relacjonują, że przeżywaja strach oraz lęk podczas wspinania. Innym przykładem osoby zmagającej się $z$ własnym strachem jest Alain Robert - wspinacz nazywany „francuskim spider-manem”, który jest znany ze wspinania się bez zabezpieczeń na najwyższe budynki świata. Robert na swojej stronie internetowej stwierdza, że nieustannie walczy z lękiem wysokości:

Wspinanie to moja pasja, moja filozofia życia. Chociaż cierpie na lęk wysokości $i$ chociaż moje wypadki pozostawiły mnie sprawnym $w 66 \%$, stałem się najlepszym wspinaczem solowym. (tekst dostępny pod adresem: www.alainrobert.com; data dostępu: 20.08.2011)

Analiza narracji wspinaczy ujawniła, że strach jest elementem stale obecnym w kontekście działania wspinaczkowego i (poza sytuacjami nagłych wypadków, w których mobilizuje organizm do walki o przetrwanie) stanowi emocję przeszkadzająca w działaniu, a sami wspinacze podejmuja aktywna pracę pozwalajaca im zmierzyć się $z$ własnym strachem i usunać go $z$ pola własnego działania.

$\mathrm{W}$ analizie tej pewna rolę odgrywały moje własne przeżycia związane ze wspinaniem, ponieważ dzięki nim mogłam lepiej zrozumieć, co czuli badani, choć niekiedy to ich werbalizacje pozwalały mi lepiej uchwycić to, co ja sama czułam. Jednakże uzyskane informacje porównywałam głównie $z$ innymi danymi o charakterze narracyjnym, traktując moje osobiste doświadczenia jedynie jako „tropy” dla dalszych poszukiwań oraz jako pytania do sprawdzenia podczas dalszych badań. 


\section{Filmy dokumentalne oraz materialy wideo}

Przypuszczałam, że pewne informacje na temat radzenia sobie ze strachem będa możliwe do uzyskania poprzez rozmowy i wywiady ze wspinaczami, ale spodziewałam się też, iż część $z$ nich nie jest możliwa do wyrażenia w słowach oraz że ważny jest sytuacyjny kontekst generujacy dane emocje. Dlatego zaczęłam analizować istniejacce materiały wideo oraz filmy dokumentalne ukazujace sytuacje wspinania. Szczególnie koncentrowałam się na tych obrazach, które zawierały w sobie sceny podejmowania ryzykownych przejść oraz manifestacje przeżywanego przez wspinaczy uczucia strachu. Poniżej odwołuję się do materiału przedstawiającego polskiego wspinacza, Adama Pustelnika (ur. 1982), w filmie Mirosława Dembińskiego pt. Pustelnicy $w$ górach.

Bohaterem obrazu filmowego jest tutaj młody, ale bardzo doświadczony wspinacz należący do elity wspinaczkowego świata ${ }^{29}$. Transkrypcja oraz opis scen (tab. 1) ujawnia wysoce emocjonalny charakter wspinaczki związany z pojawiająca się trudnością drogi, przeżywanym strachem oraz postrzeganym przez wspinacza zagrożeniem. Sfilmowana scena pokazuje wyraźnie, że wspinacz w trudnym miejscu drogi nie czuje się bezpiecznie. Brakuje mu sprzętu, który mógłby osadzić w skale i dzięki temu zapewnić sobie lepsza ochronę. Jest zły na siebie, że nie zabrał ze soba takiego sprzętu ${ }^{30}$, a bez niego boi się kontynuować wspinaczkę. Widać, że nie chce się niepotrzebnie narażać.

Tab. 1. Analizowany fragment filmu

\begin{tabular}{|l|l|}
\hline minuta & opis sceny \\
\hline $22: 17$ & $\begin{array}{l}\text { Wspinacz pokonuje droge w Yosemitach. Po kilu ruchach zatrzymuje } \\
\text { się. }\end{array}$ \\
\hline $22: 31$ & $\begin{array}{l}\text { Patrzy w góre, lustruje wzrokiem ściane usiłując wypatrzyć możli- } \\
\text { wości poruszania się na tej drodze. }\end{array}$ \\
\hline $22: 37$ & Jego wyraz twarzy wyraża zatroskanie i ostrożność. \\
\hline $22: 40$ & $\begin{array}{l}\text { Wychyla się do tyłu, aby lepiej zobaczyć chwyty i stopnie na tej dro- } \\
\text { dze. Zmienia swoja pozycję żeby mieć lepszy widok. }\end{array}$ \\
\hline
\end{tabular}

29 Adam Pustelnik ma na swoim koncie jedne $z$ najtrudniejszych dróg skalnych na świecie, np. legendarną drogę Action Directe, wyceniona na 9a na Frankenjurze.

${ }^{30} \mathrm{~Np}$. friendów lub camalotów, które można umieszczać w rysach i łączyć z nimi linę przy pomocy ekspresów uzyskując zabezpieczenie na wypadek odpadnięcia i lotu. 


\begin{tabular}{|c|c|}
\hline $22: 41$ & $\begin{array}{l}\text { Ostatecznie spedza około } 10 \text { sekund na studiowanie drogi, stojac } \\
\text { wcią̇ } w \text { jednym miejscu. }\end{array}$ \\
\hline $22: 42$ & Usiłuje utrzymać stabilna pozycje i siega do wnętrza rysy. \\
\hline $22: 43$ & Wzdycha. \\
\hline $22: 44$ & Wciska rękę do rysy. \\
\hline $22: 45$ & Pracuje ciężko. \\
\hline $22: 46$ & $\begin{array}{l}\text { Jednak } w \text { kolejnych sekundach nadal nie jest } w \text { stanie wykonać } \\
\text { następnego ruchu. }\end{array}$ \\
\hline $22: 49$ & „Kurwaaa!” - krzyczy. \\
\hline $22: 50$ & Wcią̇ próbuje ustabilizować rękę w rysie. \\
\hline $22: 59$ & Wreszcie obsuwa się $w$ dót. \\
\hline 23:00 & Ryczy: „Aaaaaaa”. \\
\hline 23:01 & Wspinacz znika z kadru. \\
\hline 23:03 & „Kurwaaa!”. Brzmi to jak irytacja lub wściekłość. \\
\hline 23:04 & Stychać metaliczne pobrzękiwanie sprzętu. \\
\hline 23:05 & Rozbrzmiewa krzyk orła. \\
\hline 23:06 & Po kilku ruchach wspinacz przemieszcza się $w$ dół. \\
\hline 23:11 & $\begin{array}{l}\text { Krzyczy: „Ja pierdole, dlaczego nie zabratem NIIIC!!!” - co ozna- } \\
\text { cza: dlaczego nie zabratem więcej sprzętu do asekuracji, żeby sie } \\
\text { poczuć bezpieczniej. }\end{array}$ \\
\hline 23:12 & Mówiac to energicznie potrzasa dłonia. \\
\hline 23:13 & $\begin{array}{l}\text { W tej samej chwili jego postawa wyraża wściekłość, frustracje z po- } \\
\text { wodu niemożności kontynuowania wspinaczki oraz lęk przed wyko- } \\
\text { naniem kolejnego ruchu. }\end{array}$ \\
\hline 23:14 & „Kurde!!!” - woła. \\
\hline $23: 17$ & $\begin{array}{l}\text { Ale już po niedługiej chwili mówi głośno: „Nie muszę się przecież } \\
\text { tu tak bać!” }\end{array}$ \\
\hline 23:18 & Po czym energicznie chwyta ręka najbliższy chwyt. \\
\hline 23:19 & $\begin{array}{l}\text { "Kurwaaaa" - krzyczy jakby dodajac sobie odwagi, ale już w na- } \\
\text { stępnej chwili powraca do stanu strachu i frustracji. Całe jego ciało } \\
\text { jest spięte. Nerwowo potrzasa dłonia. }\end{array}$ \\
\hline $23: 25$ & $\begin{array}{l}\text { Po kilku kolejnych sekundach ponownie energicznie zaczyna sie } \\
\text { znowu wspinać. }\end{array}$ \\
\hline 23:33 & Zręcznie przechodzi trudne miejsce. \\
\hline $23: 38$ & $\begin{array}{l}\text { "Ja pierdolę!" - mówi ciszej wspinajac się. Już w petni kontroluje } \\
\text { sytuację. }\end{array}$ \\
\hline $23: 45$ & $\begin{array}{l}\text { "Kurwaa” - mówi energicznie posuwajac sie do góry - „Nigdy w ży- } \\
\text { ciu sie jeszcze tak nie nasrałem bardziej... Ale z głupoty to chyba } \\
\text { wynika”. Ostatnie zdanie wypowiadane jest już z ulga, gdy wspi- } \\
\text { nacz jest już powyżej trudnego miejsca i wchodzi w tatwiejszy teren. }\end{array}$ \\
\hline
\end{tabular}

Źródło: Pustelnicy w górach, film w reżyserii Mirosława Dembińskiego, zdjęcia: Maciej Szafnicki, fragment 22:17-23:45 
W warstwie wizualnej widać wyraźnie, że emocja strachu nie występuje tutaj samodzielnie, ale miesza się $z$ gniewem, złością i wściekłością, które niejako „doenergetyzowują" wspinacza, pozwalają mu zebrać siły i napędzają do walki. Widać także, że wspinacz dokonuje pracy emocjonalnej równolegle $z$ zadaniami poznawczymi (ocena skały pod katem możliwych chwytów i stopni, podejmowaniem prób uzyskania chwytu w szczelinie rysy, lepszego balansu, praca całego ciała związaną $z$ przemieszczaniem się w górę).

Kluczowym momentem sceny jest ten, w którym wspinacz pokonuje własny strach instruując sam siebie: „Nie muszę się przecież tu tak bać!". Jest to chwila, w której ustanawia on nowa definicję sytuacji, reinterpretuje pierwotną ocenę niebezpieczeństwa drogi i podejmuje próbę. Wspinacz pokonuje swój strach redefiniując zagrożenie, określając sytuację jako taką, która nie powinna wywoływać aż tak silnego lęku przed odpadnięciem. Stwierdzenie „nie muszę się tu tak bać” odnosi się także do autodefinicji wspinacza i do jego własnej oceny swych możliwości i umiejętności wspinaczkowych. Wspinacz uzmysławia sobie, że tego typu sytuacje nie powinny stanowić dla niego problemu. Wypowiadajacc te słowa sam siebie instruuje co do oceny niebezpieczeństwa drogi oraz swoich możliwości jej pokonania. Używając słów Blumera: w procesie interakcji z samym soba podmiot „wskazuje sobie obiekty, na które skierowane jest jego działanie" (Blumer 2007 [1969]: 8).

Możemy zobaczyć, że bohater tej sceny działa wobec doświadczanego strachu, wywoływanego brakiem wystarczajacych zabezpieczeń, a obiektem pracy fizycznej jest droga, która chce pokonać. Emocje te były wyraźnie „niechciane” przez wspinacza oraz przeszkadzające i hamujące działanie. Pojawiły się jako konsekwencja postrzeganych trudności drogi oraz zwiąanej $z$ tym oceny zagrożenia. Wspinacz podczas działania musiał skonfrontować własne umiejętności $z$ wymaganiami, jakie stawia droga. Aby przekroczyć swój strach musiał wzbudzić wiarę we własne umiejętności i zredefiniować ocenę zagrożenia. Ale jednocześnie to przeżywany przez wspinacza strach połączony $z$ chęcia pokonania drogi, napędzał emocje „wspomagające” działanie - złość, wściekłość, frustrację - które ostatecznie zadecydowały o przełomie i popchnęły go do kontynuowania wspinaczki. Obserwujemy zatem „mieszane emocje", które wpływaja na działanie i strukturalizuja je.

Wielu alpinistów i wspinaczy potwierdza, że wspinanie wiąże się $z$ praca emocjonalną, a szczególna emocją, nad która się pracuje jest strach. Walka $z$ własnym strachem bywa przedstawiana jako esencja doświadczenia wspinaczkowego. 
Ten odruch sprzeciwu wobec, y wobec własnego strachu, to jest kwintesencja doznania alpinistycznego. Człowiek, który się wspina boi się oczywiście, ale przełamuje ten strach, przezwycięża siebie i pnie się do góry. (wypowiedź alpinisty Wojtka Kurtyki w filmie dokumentalnym Marka Kłosowicza pt. Ścieżka góry, 2007)

Można więc stwierdzić, że niezależnie od poziomu umiejętności wspinacza - emocje pozostaja immanentną częścią tej działalności, zwłaszcza gdy weźmiemy pod uwagę wysokie ryzyko spostrzegane przez wspinacza. Chociaż emocje stanowia zjawiska nietrwałe i ulotne - pojawiaja się zaledwie na parę sekund lub minut, a następnie znikaja i podlegaja szybkim transformacjom moga w znaczący sposób wpływać na przebieg oraz konsekwencje działania.

\section{Konkluzje - praca nad emocjami w działalności wspinaczkowej}

Wspinacze doświadczają lęku wysokości i lęku przed odpadnięciem, ale ucza się, jak pokonywać te emocje i poprawnie reagować na nie. Nowicjusz doświadcza lęku przed nieznanym, za którym kryje się, nie zawsze wypowiadany wprost, lęk przed uszkodzeniem ciała - oraz niepewność, co stanie się podczas wspinaczki, ale w tym samym momencie nadal nie zdaje sobie sprawy ze wszystkich ryzyk i zagrożeń obecnych w sytuacji wspinania.

Paradoksalnie, cały proces szkoleniowy, którego istota jest pomóc adeptowi w rozwoju wspinaczkowych umiejętności, jest $z$ jednej strony związany $z$ radzeniem sobie $z$ lękiem, $z$ drugiej zaś zawiera w sobie budzenie świadomości zagrożeń poprzez: uczenie się, jak rozpoznawać zagrożenia w sytuacji wspinania, uczenie się czujnych zachowań w skałach i w górach oraz uczenie się poprawnego reagowania na sytuację niebezpieczeństwa (odpadnięcia i lotu). Podczas kursu wspinaczkowego kluczową rolę w redefiniowaniu zagrożeń odgrywają znaczaccy inni, zwłaszcza instruktor lub bardziej doświadczony partner. Robia to na wiele sposobów - poprzez:

- wskazywanie konkretnych ruchów, jakie nowicjusz może (powinien) wykonać - fakt, że istnieje „instrukcja”, jak przejść droge normalizuje sytuację i dodaje wspinaczowi wiary, że drogę w ogóle da się przejść; 
- wyrażanie pomocnej postawy - nowicjusz wie, że jest ktoś gotowy do udzielenia mu pomocnych wskazówek; daje mu to poczucie bezpieczeństwa: ktoś wie, jak wykonać zadanie;

- wyrażanie przez znaczących innych (instruktora, bardziej doświadczonego partnera) emocji takich jak: znudzenie lub niecierpliwość - informuje nowicjusza, że sytuacja jest pod kontrolą (do znudzenia); spokój i opanowanie - informuja, że instruktor nie jest ogarnięty emocjami, które przeżywa kursant lub, że sytuacja jest bezpieczna i nie wymaga emocji („nie ma się czego bać”). To podsuwa nowicjuszowi nowa definicję sytuacji. Podczas kursu wspinaczkowego definicja instruktora jest „wiążąca” i „poprawna”, zatem w sposób naturalny zostaje narzucona;

- wyrażanie przez instruktora wiary w efektywność nowicjusza - instruktor wydaje się być całkowicie pewny, że adept wykona zadanie;

- wyrażanie przez instruktora oczekiwań, że nowicjusz przejdzie drogę;

- zachęcanie nowicjusza do działania - od przyjacielskiego „Dalej! Idziesz!”, po bezceremonialne „Rusz dupę!”, „Jak długo będziesz się tam guzdrał?”

- nagradzanie postępów adepta - poprzez różnego rodzaju eksklamacje: „Świetnie!”, „Wspaniale!”, „Super”, „Brawo!” itd.

Aby podtrzymywać działanie wspinaczkowe, poza rozwijaniem własnych fizycznych umiejętności oraz techniki poruszania się w skale, wspinacz na wczesnym etapie musi rozwinąć zaufanie do sprzętu wspinaczkowego (uprzęży, liny, węzłów, pętli, przyrządów asekuracyjnych) oraz zaufanie do partnera jako asekurującego. Musi też pokonać ucieleśnione doznanie lęku związanego $z$ wychylaniem się poza pionową oś ciała, utratą kontaktu $z$ podłożem, braku pewnego podparcia dla stóp lub widoku przepaści poniżej. Podstawowym elementem uczenia się wspinania jest redefinicja wlasnego strachu.

Kontrolowanie własnego strachu i nie pozwalanie by przeszkadzał czy zatrzymywał działanie staje się elementem rozwoju wspinacza. Podczas wspinaczki uczestnicy nieustannie wykonuja pracę nad definiowaniem zagrożeń i próbuja ocenić, jak niebezpieczna jest sytuacja. Jednak zasadniczą rolę $\mathrm{w}$ tym procesie odgrywa nabieranie zaufania do własnych umiejętności wspinaczkowych. Im bardziej wytrenowane ciało, tym większe zaufanie do własnych możliwości i poleganie na swoich umiejętnościach.

Wspinacze szybko uczą się, że można łatwiej pokonać strach, koncentrując się całkowicie na konkretnym zadaniu ruchowym. 
Każdy kolejny ruch przesuwa to ognisko uwagi. Pokonane trudności drogi natychmiast znikają $z$ pola uwagi, a następne jeszcze nie zaprzataja umysłu. Wypełnia go jedynie pokonywany aktualnie fragment drogi, znajdujący się w zasięgu rąk i stóp wspinacza konkretny ruch, sięganie do kolejnego chwytu, szukanie dobrego oparcia dla stopy, zadania, które wspinacz musi rozwiązywać „tu i teraz", a które w sumie składają się na ciąg przechwytów, którego rezultatem jest pokonana droga wspinaczkowa.

Uczenie się wspinania odbywa się stopniowo. Nowicjusz przezwycięża własne przekonania na temat limitów własnej aktywności. Zmianę techniki asekuracji - ze wspinania na wędkę na prowadzenie drogi - adept rozpoczyna zazwyczaj z niedowierzaniem, że będzie w stanie zrealizować wejście w ten sposób, ale po kilku udanych próbach jego ogląd własnych możliwości zmienia się. Efektem takiego przeskoku od „niemożliwego” do „możliwego” jest poszerzanie perspektywy, w której widzi się własne wspinanie oraz postrzeganie rozwoju jako pokonywanie coraz trudniejszych dróg.

$\mathrm{W}$ tym sensie, doświadczenie panicznego strachu, po którym nastapił sukces przejścia drogi, dostarcza jednostce nowej perspektywy działania, w której pośród wielu różnych reakcji na sytuację zagrożenia istnieje jedna - „bycie wolnym od paniki” i wspinacz powinien się nauczyć, jak ją osiagać. Stoicki sposób reagowania na zagrożenia spotyka się $z$ aprobata we wspinaczkowym świecie. Również reakcje takie jak: złość, gniew, frustracja wyrażane krzykiem, impulsywnymi ruchami ciała lub przeklinaniem - sa akceptowane i dopuszczalne. Nowicjusz szybko orientuje się, że wpadanie w panikę nie jest aprobowanym sposobem reakcji na strach przeżywany podczas wspinania. $\mathrm{W}$ rezultacie adept odrzuca panikę jako reakcję niestosowna i niewłaściwą podczas wspinania. Nie oznacza to, że nigdy mu się ona nie zdarzy. Jednakże będzie ja rozładowywał w inny sposób - reagując właśnie gniewem lub krzykiem, a nie paraliżująca ruchy paniką.

Jeśli wspinacz, któremu nie udało się pokonać drogi $z$ powodu własnego strachu, odczuwa wstyd $z$ powodu własnej nieporadności i odbiera swoja porażkę jako emocję nieprzyjemna - istnieje możliwość, że w przyszłości rozwinie postawę przełamywania strachu, by zyskać aprobatę otoczenia. Nowicjusz może być też rozczarowany, że droga, która kosztowała go wiele wysiłku jest nisko wyceniona, toteż biorąc pod uwagę sposoby wartościowania osiągnięć we wspinaczkowym świecie będzie chciał przechodzić coraz trudniejsze drogi. Chociaż wspinacz nie spotyka się prawie nigdy $z$ żadna negatywną ocena werbalną swoich działań - zazwyczaj odczuwa brak satysfakcji, jeśli nie pokona drogi. 
Doświadczenie panicznego strachu graniczącego $z$ walką o życie może także powodować zablokowanie działania oraz czasowe (lub trwałe) zawieszenie działalności wspinaczkowej. Jednakże ukończenie drogi pomimo faktu doświadczania strachu sprawia, że wspinacz oswaja się $z$ trudnymi sytuacjami. Doświadczenie przechodzenia nad przepaścią, pokonywania lęku wysokości może formatować przyszła gotowość do mierzenia się $z$ takimi problemami. Strach staje się wówczas jednym $z$ elementów sytuacji wspinania. Nie powstrzymuje działania, ale towarzyszy mu. Wspinacz zaznajamia się ze strachem i bez wahania wchodzi w trudne drogi.

Strach wzrasta, gdy działanie wykonywane jest po raz pierwszy (np. pierwsze prowadzenie drogi) lub gdy wspinacz popełnia błędy zmniejszające bezpieczeństwo wspinaczki (np. wejście w trudne miejsce bez wystarczajacego zabezpieczenia). Dodatkowymi utrudniającymi działanie okolicznościami są: złe warunki pogodowe, bardzo niska lub bardzo wysoka temperatura, silny wiatr, opady atmosferyczne. Strach powraca również, gdy spada kondycja wspinacza (np. na skutek zmęczenia, długotrwałości akcji górskiej lub długiej przerwy we wspinaniu) i gdy czuje on, że nie może w pełni polegać na własnym ciele.

Poprawnym sposobem reagowania na doświadczany strach jest pokonywanie go. Prawidłowe sposoby radzenia sobie $z$ własnym strachem podsuwane sa przez znaczacych innych: instruktorów, kolegów. Dodatkowym źródłem motywacji do redefiniowania strachu jest doświadczanie silnych pozytywnych emocji związanych $z$ wielkim wysiłkiem, ekscytacja, euforia, radością i duma, które odczuwało się podczas pierwszych łatwych wspinaczek, a które definiuja oczekiwania co do przyszłych doświadczeń wspinaczkowych. W rezultacie wspinacze wykształcaja chęć rozwoju, progresu, podnoszenia wspinaczkowych umiejętności i radzenia sobie ze strachem w trudnych sytuacjach.

\section{Autoetnografia w badaniach nad emocjami - wnioski metodologiczne}

W zaprezentowanej analizie autoetnografia stanowiła ścieżkę prowadząca do odkrycia znaczacych danych na temat studiowanej działalności. Moja własna połączona aktywność badacza oraz wspinacza umożliwiła wygenerowanie doświadczeń pozwalajacych poczuć i zrozumieć podstawowe uwarunkowania wspinaczki dostęp- 
ne jedynie uczestnikom. Nie traktowałam tych moich osobistych wrażeń i impresji jako „modelowych” ilustracji procesów będących przedmiotem badania. Były one raczej wskazówka, tropem możliwym do dalszego prześledzenia i zbadania.

Moje podejście wyraźnie skłania się ku autoetnografii analitycznej zaproponowanej przez Leona Andersona - zawiera w sobie kluczowe cechy tego podejścia: (i) badacz przyjmuje status pełnego uczestnika badanych sytuacji, (ii) wykazuje się refleksyjnością analityczna, (iii) badacz jest narracyjnie „widoczny” w tekście, (iv) podejmuje dialog $z$ informatorami poza samym sobą, (v) angażuje się w rozważania teoretyczne (Anderson 2006: 378).

W mojej analizie porównywałam i zestawiałam ze sobą różne rodzaje danych autoetnograficznych, a także dane $z$ różnych źródeł (zob. ryc. 1). Po pierwsze, tworzyłam teksty autoetnograficzne ex-post, co polegało na kilkakrotnym konstruowaniu opisu tej samej sytuacji oraz porównywanie ze soba tych różnych wersji opisu w poszukiwaniu istoty opowiadanej historii, spójnej wizji opisywanej sytuacji w celu wyizolowania rdzenia - zasadniczej treści powtarzanej w każdej wersji. Śledziłam przyczyny pojawiających się rozbieżności pomiędzy historyjkami. Po drugie, porównywałam autoetnograficzne teksty pisane ex-post $z$ moimi notatkami terenowymi sprawdzając, czy czegoś nie pominęłam, nie przeoczyłam lub zapomniałam. Czy pewne fragmenty opowieści nie zostały przemilczane, pominięte, zapomniane lub zmienione pod względem chronologicznym. Powtarzałam taki zabieg w odniesieniu do każdego źródła. Po trzecie, porównywałam różne materiały i źródła informacji: notatki terenowe, zdjęcia prezentujace dane sytuacje, teksty autoetnograficzne pisane ex-post $-z$ tym, co pozostało w pamięci. Po czwarte, porównywałam moja własną opowieść $z$ historiami innych wspinaczy w kontekście doświadczanego lęku oraz strachu podczas wspinania - w wywiadach - będac świadoma, jakie przypadki (ang. instances) ze soba zestawiam. Na przykład, rozpatrujac sytuacje wspinania w wykonaniu początkujacych wspinaczy zestawiałam je $z$ własnymi doświadczeniami, ale dla doświadczeń wybitnych wspinaczy poszukiwałam innego kontekstu porównań. Po piąte, porównywałam moją własna opowieść $z$ innymi danymi zastanymi - na przykład $z$ narracjami autobiograficznymi opisujaccymi podobne sytuacje. Po szóste, zestawiałam dane na temat początkowych doświadczeń wspinaczkowych $z$ danymi prezentujacymi przejścia doświadczonych wspinaczy, mając na uwadze przeżywane w obydwu przypadkach emocje strachu. 
Gromadzenie danych

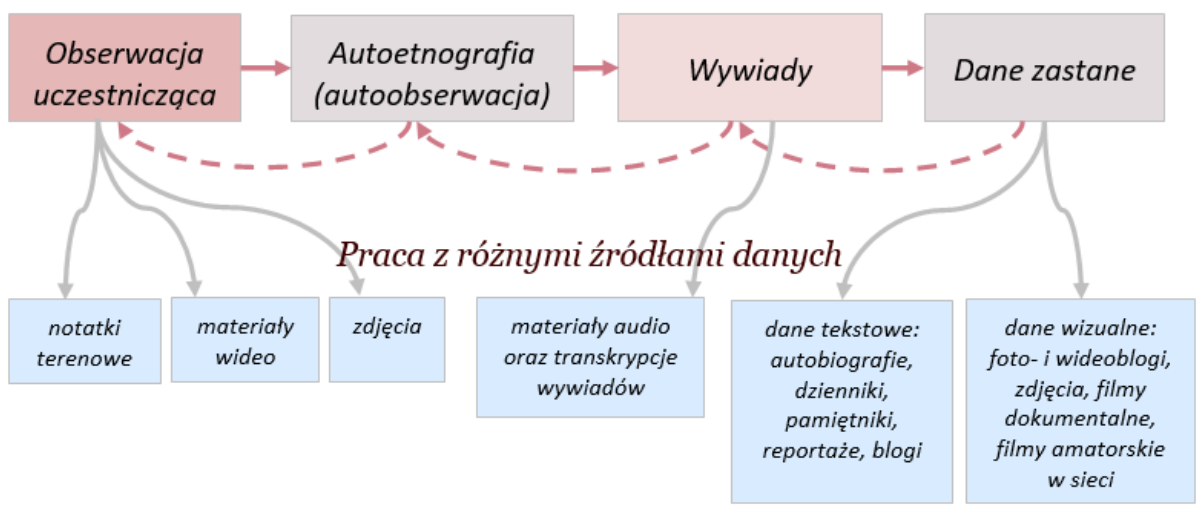

Porównywanie danych

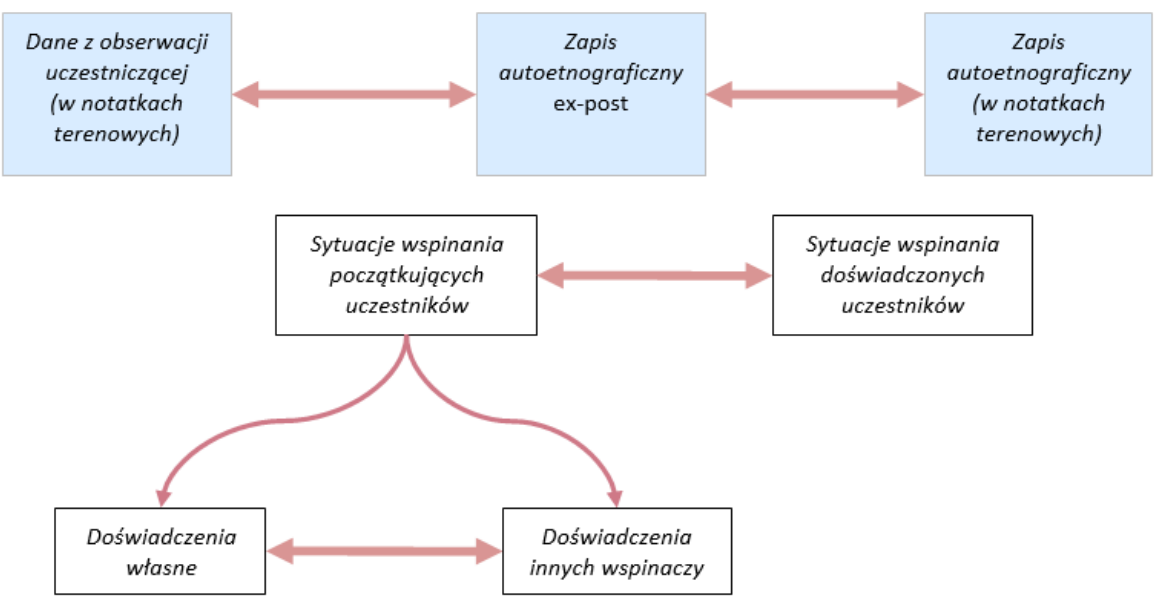

Ryc. 1. Aktywność poznawcza badacza podczas procesu analitycznego

Źródło: opracowanie własne

Te dane odnoszące się do stanów emocjonalnych (zarówno moich własnych, jak i moich badanych oraz innych obserwowanych lub opisywanych ludzi) były poddawane procedurom analitycznym typowym dla metodologii teorii ugruntowanej. Szukałam własności wygenerowanych kategorii analitycznych - w tym przypadku dotyczacych ekspresji, opisu lub sposobu doświadczania emocji podczas działalności wspinaczkowej oraz ich sytuacyjnych uwarunko- 
wań. Porównywałam stany emocjonalne wspinaczy znajdujących się w różnych kontekstach sytuacyjnych oraz na różnym poziomie wspinaczkowej kariery - budując hipotezy dotyczace pracy nad emocjami w działalności wspinaczkowej.

Autoetnografia, autoobserwacja, zapamiętane fakty i wydarzenia, wrażenia zapisane $\mathrm{w}$ pamięci - spisane $\mathrm{w}$ notatkach terenowych służyły za punkt odniesienia dla danych pozyskanych $z$ innych źródeł. Wydaje mi się, że bez odwołania do autoetnografii próba opisu emocji doświadczanych przez wspinaczy byłaby spojrzeniem zbyt zewnętrznym. $Z$ analitycznego punktu widzenia zarówno doświadczane emocje, jak i ucieleśnione odczucia stanowia istotne źródło danych. Każda informacja może stać się nowym źródłem hipotez i podstawa nowego wzorca rozumienia oraz kodowania pozostałych danych.

Autoetnografia może posłużyć jako źródło danych, o ile badacz jest w stanie wyrazić w słowach własne doświadczenia jako działajacego uczestnika badanych sytuacji, zanurzonego w studiowanym fenomenie. Jest to jeden $z$ ważniejszych, szeroko dyskutowanych i powracających problemów - do jakiego stopnia możliwa jest werbalizacja i zamknięcie w pisanej, narracyjnej formie tego, co się czuje i czego się doświadcza (van Maanen 2011; Kacperczyk 2014). W moim badaniu próba obiektywizacji tego rodzaju źródeł polegała na włączaniu pisemnych autoetnograficznych materiałów oraz poddawaniu ich procedurze kodowania oraz porównywania. Te źródła danych traktowane były w taki sam sposób jak pozostałe zdobyte w procesie badawczym informacje, czyli $z$ uwzględnieniem umiejscowienia oraz cech kontekstu, w którym zostały wygenerowane i do którego się odnoszą.

Autoetnografia pozwala śledzić proces „doskonalenia” badacza jako instrumentu poznawczego i daje mu unikalną szansę sięgania do doświadczeń pozwalających głębiej poznać i zrozumieć badaną działalność. Daje również wgląd w postępy procesu poznawczego oraz pewnego rodzaju kontrolę nad nim poprzez uświadomienie sobie tego, co ja sama jako badacz wprowadzam do procesu badania.

Uczestnictwo w działaniach wspinaczkowych zmieniło mnie sama jako badacza i jako wspinacza (por. Kacperczyk 2012), transformując moja gotowość do zmagania się $z$ własnymi uczuciami oraz przeszkodami emocjonalnymi. Doświadczane emocje poszerzyły moja perspektywę oraz pogląd na temat tego, co jest możliwe w moim własnym rozwoju wspinaczkowym, a jednocześnie otworzyły możliwość uzyskania wglądu w badaną działalność wspinaczkową. 
Proces śledzenia emocjonalnych aspektów aktywności wspinaczkowej uwrażliwił mnie na pewne niepozorne aspekty doświadczenia stawania się wspinaczem. Wspinanie wymaga rozwijania sprawności fizycznej $\mathrm{w}$ poruszaniu się po wertykalnych ścieżkach oraz operowania sprzętem wspinaczkowym, ale także kontrolowania własnych stanów emocjonalnych pojawiających się w związku z ucieleśnionym doświadczeniem wspinania. Nabywanie „poprawnej” postawy wobec podejmowanej oraz studiowanej działalności - w moim przypadku - odbywało się poprzez niezauważalne podporządkowywanie się perspektywie znaczacych innych oraz przejmowanie ich punktu widzenia. W samym procesie analitycznym ja sama byłam zaskoczona, jak łatwo poddałam się im i jak późno to odkryłam. Transformacje, jakim podlegał mój własny ogląd działania wspinaczkowego zostały zrekonstruowane dopiero kilka lat po zdarzeniach, które do nich prowadziły, a ich znaczenie możliwe było do uchwycenia dopiero retrospektywnie. W momencie zdarzenia stanowiły jedynie strumień intensywnie przeżywanych emocji.

\section{Bibliografia}

Anderson L.

2006 Analytic autoethnography, „Journal of Contemporary Ethnography", t. 35, nr 4, s. 373-395.

2014 Autoetnografia analityczna, przeł. M. Brzozowska-Brywczyńska, „Przegląd Socjologii Jakościowej”, t. 10, nr 3, s. 144-167, (tekst dostępny pod adresem: http://www.qualitativesociologyreview.org/PL/Volume27/PSJ_10_3_Anderson.pdf; data dostępu: 01.09.2014).

Becker H.S.

1974 Art as collective action, „American Sociological Review”, t. 39, nr 6, s. 767-776.

1982 Art worlds, Berkeley.

1986 Doing things together, Evanston.

Blumer $\mathrm{H}$.

2007 [1969] Interakcjonizm symboliczny. Perspektywa $i$ metoda, przeł. G. Woroniecka, Kraków.

Brownell S.

2006 Sport ethnography. A personal account, [w:] R. Wright (red.), The Sage handbook of fieldwork, London-Thousand Oaks-New Delhi, s. 243-254. 
Charmaz K.

2009 Teoria ugruntowana. Praktyczny przewodnik po analizie jakościowej, przeł. B. Komorowska, red. nauk. K. Konecki, Warszawa.

Clarke A.E.

1987 Research materials and reproductive science in the United States 1910-1940, [w:] G.L. Geison (red.), Physiology in the American context 1850-1940, Bethesda, s. 323-350.

1990 A social worlds research adventure. The case of reproductive science, [w:] S. Cozzens, T. Gieryn (red.), Theories of science in society, Bloomington, s. 15-42.

1991 Social worlds/arenas theory as organizational theory, [w:] D.R. Maines (red.), Social organization and social process. Essays in honor of Anselm Strauss, New York, s. 119-158.

2003 Situational analyses. Grounded theory mapping after the postmodern turn, „Symbolic Interaction”, t. 26, nr 4, s. 553-576.

2005 Situational analysis. Grounded theory after the postmodern turn, Thousand Oaks.

Clifford J.

1986 Introduction. Partial truths, [w:] J. Clifford, G. Marcus (red.), Writing culture. The poetics and politics of ethnography, Berkeley, s. 1-26.

Cressey P.G.

2008 [1932] The taxi-dance hall. A sociological study in commercialized recreation and city life. Chicago.

Fujimura J.H.

1996 Crafting science. A sociohistory of the quest for the genetics of cancer, Cambridge.

1997 The molecular biological bandwagon in cancer research. Where social worlds meet, [w:] A.L. Strauss, J. Corbin (red.), Grounded theory in practice, Thousand Oaks, s. 95-130.

Goddard D., Neuman U.

1994 Performance rock climbing, Mechanicsburg.

Glaser B.G.

1978 Theoretical sensitivity. Advances in the methodology of grounded theory, Mill Valley.

Glaser B.G., Strauss A.L.

2009 [1967] Odkrywanie teorii ugruntowanej. Strategie badania jakościowego, przeł. M. Gorzko, Kraków.

Kacperczyk A.

2005 Zastosowanie koncepcji społecznych światów w badaniach empirycznych, [w:] E. Hałas, K. Konecki (red.), Konstruowanie jaźni $i$ społeczeństwa. Europejskie warianty interakcjonizmu symbolicznego, Warszawa, s. 169-191.

2010 "Ludzie gór”. Procesy tożsamościowe uczestników społecznego świata w konfrontacji z przyrodą nieożywiona, [w:] K.T. Konecki, 
A. Kacperczyk (red.), Procesy tożsamościowe. Symboliczno-interakcyjny wymiar konstruowania ładu i nieładu społecznego, Łódź, s. 165-178.

2012 Badacz $i$ jego ciało $w$ procesie zbierania $i$ analizowania danych - na przykładzie badań nad społecznym światem wspinaczki, „Przegląd Socjologii Jakościowej”, t. 8, nr 2, s. 32-63, (tekst dostępny pod adresem: www.przegladsocjologiijakosciowej.org).

2013 Praca nad emocjami jako element aktywności górskiej $i$ wspinaczkowej, „Przegląd Socjologii Jakościowej”, t. 9, nr 2, s. 70-103, (tekst dostępny pod adresem: www.przegladsocjologiijakosciowej.org).

2014 Autoetnografia - technika, metoda, nowy paradygmat? O metodologicznym statusie autoetnografii, „Przegląd Socjologii Jakościowej”, t. 10, nr 3, s. 32-74, (tekst dostępny pod adresem: www.przegladsocjologiijakosciowej.org).

2016 Spoleczne światy. Teoria - empiria - metody badań. Na przykładzie społecznego świata wspinaczki, Łódź.

Kling R., Gerson E.M.

1977 The social dynamics of technical innovation in the computing world, „Symbolic Interaction”, t. 1, nr 1, s. 132-146.

1978 Patterns of segmentation and intersection in the computing world, „Symbolic Interaction”, t. 1, s. 24-43.

Konecki K.T.

2000 Studia z metodologii badań jakościowych. Teoria ugruntowana. Warszawa.

Kozinets R.V.

1998 On netnography. Initial reflections on consumer research investigations of cyberculture, "Advances in Consumer Research", t. 25 , s. $366-371$.

Lutz C.A.

1988 Unnatural emotions. Everyday sentiments on a Micronesian Atoll and their challenge to western theory, Chicago.

McGrath D., Elison J.

2014 Vertical mind. Psychological approaches for optimal rock climbing, Boulder.

Prus R.

1996 Symbolic Interaction and ethnographic research. Intersubjectivity and the study of human lived experience, New York.

Shibutani T.

1955 Reference groups as perspectives, „American Journal of Sociology", t. 60, nr 6, s. 562-569.

Schachter S.S.

1971 Emotion, obesity, and crime, New York.

Shott S.

1979 Emotion and social life. A symbolic interactionist analysis, „The American Journal of Sociology”, t. 84, nr 6, s. 1317-1334. 
Star S.L.

1989 Regions of the mind. Brain research and the quest for scientific certainty, Stanford.

Strauss A.L.

1978 A social worlds perspective, [w:] N.K. Denzin (red.), Studies in symbolic interaction, Greenwich, s. 119-128.

1987 Qualitative analysis for social scientists, Cambridge.

1993 Continual permutations of action, New York.

2013 [1959] Zwierciadła i maski. W poszukiwaniu tożsamości, przeł. E. Hałas, Kraków.

Strauss A.L., Schatzman L., Bucher R., Ehrlich D., Sabshin M.

1964 Psychiatric ideologies and institutions, Glencoe.

Van Maanen J.E.

2011 Tales of the field. On writing ethnography, Chicago.

Warren C.A.B.

1979 The social construction of dangerousness, „Journal of Contem-

Wiener C. porary Ethnography”, t. 8, nr 3, s. 359-384.

1981 The politics of alcoholism. Building an arena around a social problem, New Brunswick. 